\title{
Enhanced NiO dispersion on a high surface pillared heterostructure covered by niobium leads to an optimal behaviour in the ODH of ethane
}

By

Enrique Rodríguez-Castellón ${ }^{[\mathrm{a}]^{*}}$, Daniel Delgado ${ }^{[\mathrm{b}]}$, Ana Dejoz $^{[\mathrm{c}]}$, Isabel Vázquez ${ }^{[\mathrm{c}]}$, Said Agouram ${ }^{[\mathrm{d}]}$, Juan A. Cecilia ${ }^{[\mathrm{a}]}$, Benjamín Solsona ${ }^{[\mathrm{c}]}$, José M. López Nieto ${ }^{[\mathrm{b}]^{*}}$

[a] Departamento de Química Inorgánica, Facultad de Ciencias, Universidad de Málaga, 29071 Málaga, Spain. E-mail: castellon@uma.es

${ }^{[b]}$ Instituto de Tecnología Química, Universitat Politècnica de València-Consejo Superior de Investigaciones Científicas, Avenida de los Naranjos s/n, 46022 Valencia, Spain. E-mail: jmlopez@itq.upv.es

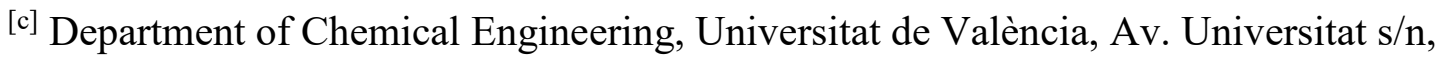
46100 Burjassot-Valencia, Spain. E-mail: Benjamin.Solsona@uv.es

[d] Department of Applied Physics and Electromagnetism, Universitat de València, C/Dr. Moliner 50, 46100 Burjassot, Valencia, Spain

*Enrique Rodríguez Castellón E-mail: castellon@uma.es, José Manuel López Nieto Email: jmlopez@itq.upv.es 


\begin{abstract}
$\mathrm{Nb}$-containing siliceous porous clay heterostructure $(\mathrm{PCH})(\mathrm{Nb}$-content from 0 to 30 $\mathrm{wt} \%$ ), prepared from a bentonite, has been used as effective support in the preparation of supported $\mathrm{NiO}$ catalysts (with $\mathrm{NiO}$ loading from 15 to $80 \mathrm{wt} \%$ ). Supports and $\mathrm{NiO}$ containing catalysts have been characterized by several physicochemical techniques, and tested in the oxidative dehydrogenation of ethane. The characterization results on $\mathrm{Nb}-$ containing supports show the presence of well-anchored $\mathrm{Nb}^{5+}$ species, without the formation of $\mathrm{Nb}_{2} \mathrm{O}_{5}$ crystals. A high dispersion of nickel oxide (which presents a low crystallinity) has been observed when using the $\mathrm{Nb}$-containing $\mathrm{PCH}$ supports. In addition, when $\mathrm{NiO}$ is supported on these $\mathrm{Nb}$-containing porous clays, it displays a higher effectiveness in the ODH of ethane (ethylene selectivity of ca. $90 \%$ ) than NiO supported on the corresponding $\mathrm{Nb}$-free siliceous $\mathrm{PCH}$ or on $\mathrm{Nb}_{2} \mathrm{O}_{5}$ (ethylene selectivity of ca. 30 and $60 \%$, respectively). Factors such as the $\mathrm{NiO}-\mathrm{Nb}^{5+}$ interaction, $\mathrm{NiO}$ particle size and the properties of surface $\mathrm{Ni}^{\mathrm{n}+}$ species have shown to be determining for the catalytic performance.
\end{abstract}

Keywords: ODH of ethane; supported nickel oxide; niobium oxide: heterostructure. 


\section{Introduction}

The petrochemical industry presents two opposing forces in terms of the consumption pattern of its products. On the one hand, the decrease in the use of oil derivatives as fuels makes the future of petrochemicals look bright. ${ }^{[1]}$ On the other hand, the future and present restrictions on the use of non-reusable and non-biodegradable plastics suggest a negative trend..$^{[2,3]}$

Overall, the drastic reduction of oil as a fuel source opens a wide range of possibilities for oil to be used as raw material. Nowadays, ethylene is probably the most important feedstock of petrochemistry and it is very likely that its production will grow in the next years. ${ }^{[4]}$ Unfortunately, the non-catalytic "steam cracking", which is the main route currently used for ethylene production, is one of the most energy-consuming processes in the chemical industry. ${ }^{[5,6]}$ Among alternative processes, the catalytic oxidative dehydrogenation $(\mathrm{ODH})$ of ethane, an exothermic reaction, stems as an interesting pathway that can sort out the main energy problem of steam cracking process. ${ }^{[7-9]}$ For instance, in $\mathrm{ODH}$ an in situ re-oxidation of the surface of the catalyst takes place, what prevents its deactivation. Moreover, the fact that oxygen is fed together with ethane avoids coke formation, although carbon oxides are formed. In fact, the excessive formation of carbon oxides (COx), with the subsequent decrease in the selectivity to ethylene), is probably the main drawback reported up to date. Despite this, there exist two promising catalytic systems able to minimize undesired COx formation for the $\mathrm{ODH}$ of ethane: i) multicomponent MoVTeNb mixed oxides $;^{[10-11]}$ and ii) promoted or diluted $\mathrm{NiO}$ catalysts catalysts. $^{[12-13]}$

$\mathrm{NiO}$ system can be considered a paradigmatic example of a host structure in which surface redox properties can be modulated to favour selective pathways in partial oxidation 
reactions.${ }^{[13-31]}$ For example, unmodified $\mathrm{NiO}$ acts as a poor catalyst in the ODH of ethane, as it tends to transform ethane mainly into carbon dioxide, showing a low ability for ethylene formation. However, if doped/promoted with a suitable transition metal, ${ }^{[13-22]}$ or diluted/supported on an appropriate metal oxide, ${ }^{[23-26]}$ the formation of carbon dioxide can be minimized, thus reaching high selectivity to ethylene. Despite this, support/diluted- or dopant/promoter-induced effects, which provoke such a selectivity shift towards ethylene formation, are still unclear. For instance, a decrease in the electrical conductivity, ${ }^{[27,28]}$ the reduction of $\mathrm{NiO}$ crystallite size, ${ }^{[29,30]}$ generation of defects, ${ }^{[25,30]}$, or the elimination of non-selective oxygen species ${ }^{[25,31]}$ have been claimed as common effects that increase ethylene selectivity in the ODH of ethane, for both promoted and supported/diluted $\mathrm{NiO}$ catalysts.

Recently, we have compared the role of both $\mathrm{Nb}^{5+}$ or $\mathrm{Ti}^{4+}$ as promoters and their corresponding oxides as supports (i.e. $\mathrm{Nb}_{2} \mathrm{O}_{5}$ and $\left.\mathrm{TiO}_{2}\right) \cdot{ }^{[26]} \mathrm{NiO}$ catalysts, either promoted with $\mathrm{Ti}^{4+}$ or supported on $\mathrm{TiO}_{2}$, display high selectivity to ethylene in the ODH of ethane (ca. $90 \%$ selectivity). Conversely, a different trend is observed for $\mathrm{Nb}^{5+}$ or $\mathrm{Nb}_{2} \mathrm{O}_{5}$ in promoted or supported $\mathrm{NiO}$-based catalysts. The incorporation of $\mathrm{Nb}^{5+}$ as dopant leads to highly selective catalysts (ethylene selectivity of ca. $90 \%$ ), as suggested previously. ${ }^{[12-18]}$ On the other hand, supported $\mathrm{NiO} / \mathrm{Nb}_{2} \mathrm{O}_{5}$ catalysts do not exceed a $60-65 \%$ selectivity to ethylene, ${ }^{[31]}$ due to an ineffective active phase-support interaction.

Accordingly, in the present work we have evaluated the possibility to prepare a supported $\mathrm{NiO}$ catalyst, with the presence of dispersed niobium species on the support, in order to selectively transform ethane into ethylene by ODH. For this purpose, a bentonite has been modified to obtain a structure with higher surface area, denoted as porous clay heterostructure $(\mathrm{PCH})$. This porous material was used as support to disperse $\mathrm{Nb}_{2} \mathrm{O}_{5}(\mathrm{Nb}-$ content from 0 to $30 \mathrm{wt} . \%$ of $\mathrm{Nb}_{2} \mathrm{O}_{5}$ ) and $\mathrm{NiO}$ (with $\mathrm{NiO}$ loading from 15 to $80 \mathrm{wt} . \%$ ). 
This catalytic system was evaluated in the ODH of ethane. The results are discussed in terms of the ability of surface $\mathrm{Nb}^{5+}$ species present on $\mathrm{PCH}$ to modify the physicochemical characteristics of $\mathrm{NiO}$.

\section{Results}

\section{Characterization of supports}

Physicochemical characteristics of supports (i.e. $\mathrm{Nb}$-free and $\mathrm{Nb}$-containing siliceous porous clay heterostructure, with $\mathrm{Nb}$-content from 0 to $30 \mathrm{wt} . \% \mathrm{Nb}_{2} \mathrm{O}_{5}$ ) are summarized in Table 1.

In a first approximation, supports were analysed by powder X-ray diffraction (XRD), and their corresponding XRD patterns are displayed in Figure S1 (Supporting information). The first important feature observed in XRD profiles is that Bragg lines corresponding to crystalline $\mathrm{Nb}_{2} \mathrm{O}_{5}$ are not observed in any of $\mathrm{Nb}$-containing supports. Considering that pseudohexagonal $\mathrm{Nb}_{2} \mathrm{O}_{5}$ phase is already formed at $500{ }^{\circ} \mathrm{C},{ }^{[32]}$ its absence could indicate that well-anchored $\mathrm{NbO}_{\mathrm{x}}$ species are formed on $\mathrm{PCH}$ surface, as it will be discussed below.

To shed some light on the nature of these niobium species, supports were studied by means of diffuse reflectance UV-VIS spectroscopy. Figure 1 shows diffuse reflectance UV-VIS spectra of $\mathrm{Nb}_{2} \mathrm{O}_{5}$ and $\mathrm{Nb}-\mathrm{PCH}$ supports. Interestingly, $\mathrm{Nb}$-free $\mathrm{PCH}$ support shows negligible absorption (Figure 1, spectra a). According to this, the sharp absorption signals found in all $\mathrm{Nb}$-containing supports (Figure 1, spectra $b$ to $e$ ) must arise from electronic transitions due to the presence of $\mathrm{Nb}$ species on $\mathrm{PCH}$. In this sense, the absorption edge is shifted to higher wavenumbers when the amount of $\mathrm{Nb}$ on the support increases. We have estimated the band-gap energies by applying Tauc's method ( $\left.\mathrm{E}_{\mathrm{gap}}\right)$ 
(see Table 1, and insets in Figure 1). ${ }^{[33,34]}$ It can be noted that $E_{\text {gap }}$ values differ for Nbcontaining PCH supports (i.e. supports B, C and D with $\mathrm{E}_{\text {gap }}$ between 4.3-4.4 eV) and bulk $\mathrm{Nb}_{2} \mathrm{O}_{5}\left(\mathrm{E}_{\mathrm{gap}}=3.4 \mathrm{eV}\right)$, underlining the different nature of $\mathrm{Nb}$ species in both materials.

Figure 1. Diffuse reflectance UV-VIS spectra and their corresponding Tauc plots of supports. a) Support A (PCH); b) Support B (5 wt.\% $\mathrm{Nb}_{2} \mathrm{O}_{5}$ on $\left.\mathrm{PCH}\right)$; c) Support C (15 wt. $\% \mathrm{Nb}_{2} \mathrm{O}_{5}$ on $\mathrm{PCH}$ ); d) Support D (30 wt.\% $\mathrm{Nb}_{2} \mathrm{O}_{5}$ on $\left.\mathrm{PCH}\right)$; e) $\mathrm{Nb}_{2} \mathrm{O}_{5}$.

The position of the absorption edge (and subsequently Egap values) is directly dependent on the electronic structure of the absorbing species, which is linked to their specific chemical environment and structural features. ${ }^{[35]}$ According to the structural and spectroscopic analysis of supports, this shift to higher energy band-gaps in $\mathrm{Nb}$-containing $\mathrm{PCH}$ materials can be ascribed to the presence of well-anchored $\mathrm{Nb}^{5+}$ sites, rather than to the formation of $\mathrm{Nb}_{2} \mathrm{O}_{5} \cdot{ }^{[36]}$ This improved dispersion of $\mathrm{Nb}^{5+}$ would be responsible for the hindered sinterization towards $\mathrm{Nb}_{2} \mathrm{O}_{5}$. These findings are in agreement with the characterization results reported by Kondo and coworkers, ${ }^{[36]}$ who found a similar effect on $\mathrm{NbO}_{\mathrm{x}}-\mathrm{SBA}-15$ system, in which the authors were able to control the growth of monobi- and tri-layered niobium oxide on the surface of the mesoporous silica, without $\mathrm{Nb}_{2} \mathrm{O}_{5}$ formation. The analyses of the supports by TEM and EDX show the homogeneous distribution of $\mathrm{Nb}$ on the porous support (Fig. S2, Supporting Information).

The surface chemical nature of these $\mathrm{Nb}$ species was analysed by XPS. Figure 2 presents $\mathrm{Nb} 3 d$ core-level XPS spectra of Nb-containing supports, showing $\mathrm{Nb} 3 d_{5 / 2}$ lines in the range $207-208 \mathrm{eV}$, typical of $\mathrm{Nb}^{5+}$ species. ${ }^{[37,38]}$ 
Figure 2. $\mathrm{Nb} 3 \mathrm{~d}$ core-level XPS spectra of $\mathrm{Nb}$-containing supports, i.e. supports $\mathrm{B}, \mathrm{C}$ and D. For comparison the spectrum of pure $\mathrm{Nb}_{2} \mathrm{O}_{5}$ has been also included.

It can be observed that $\mathrm{Nb} 3 d_{5 / 2}$ peak shifts to higher binding energies for $\mathrm{Nb}$-containing PCH supports $($ B.E. $=207.9 \mathrm{eV})$, with respect to bulk $\mathrm{Nb}_{2} \mathrm{O}_{5}($ B.E. $=207.0 \mathrm{eV})($ Figure 2). This effect goes in line with our previous statements, by which an effective interaction between $\mathrm{Nb}^{5+}$ and $\mathrm{PCH}$ support gives rise to dispersed $\mathrm{Nb}^{5+}$ sites, displaying a different chemical nature than those $\mathrm{Nb}$ entities found in $\mathrm{Nb}_{2} \mathrm{O}_{5} .{ }^{[36]}$

\section{Characterization of supported $\mathrm{NiO}$ catalysts}

Taking into consideration the different nature of $\mathrm{Nb}$ species detected on the supports, we have carried out the synthesis of a series of supported $\mathrm{NiO}$ catalysts. The physicochemical features of supported catalysts are summarized in Table 2.

Figure 3 displays powder XRD patterns of supported $\mathrm{NiO}$ materials. All the catalysts present the characteristic diffraction lines of NiO (Fm3m, JCPDS: 04-0835). Depending on the type of support and on NiO-loading, changes in the diffraction profiles are observed, especially in line-broadening of $\mathrm{NiO}$ peaks. FWHM of Bragg peaks is directly related with average crystallite size of $\mathrm{NiO}$, which has been reported to be one of the key factors to increase the activity and selectivity of these materials in the ODH of ethane. ${ }^{[29,}$ 39]

For instance, increasing NiO-loading on Support $\mathrm{C}\left(15\right.$ wt. $\% \mathrm{Nb}_{2} \mathrm{O}_{5}$ on $\left.\mathrm{PCH}\right)$ decreases $\mathrm{NiO}$ diffraction line width, indicating an increase in $\mathrm{NiO}$ particle size (Figure 3a and Table 2). On the other hand, when comparing different supports at a fixed NiO loading 
(50 wt.\% NiO), width of $\mathrm{NiO}$ Bragg peaks increases with $\mathrm{Nb}$ content on $\mathrm{PCH}$ (from 0 to 15 wt. $\% \mathrm{Nb}_{2} \mathrm{O}_{5}$ ) (Figure 3b, $50 \mathrm{Ni} / \mathrm{A}, 50 \mathrm{Ni} / \mathrm{B}$ and $50 \mathrm{Ni} / \mathrm{C}$, respectively). This indicates a decrease of $\mathrm{NiO}$ crystallite size when relatively low amounts of $\mathrm{Nb}$ are incorporated on PCH (Table 3), suggesting an effective interaction between the support and NiO. However, if higher $\mathrm{Nb}$-loadings are incorporated $\left(50 \mathrm{Ni} / \mathrm{D}, 30 \mathrm{wt} . \% \mathrm{Nb}_{2} \mathrm{O}_{5}\right.$ on $\left.\mathrm{PCH}\right)$, the average $\mathrm{NiO}$ particle size increases drastically, as it can be inferred from the narrow $\mathrm{NiO}$ peaks observed for 50Ni/D catalyst (Figure 3b and Table 2). In addition, no Bragg peaks corresponding to $\mathrm{Nb}_{2} \mathrm{O}_{5}$ phases were detected in any catalyst.

Figure 3. XRD patterns of supported $\mathrm{NiO}$ catalysts. Characteristics of catalysts in Table 1. For comparison the $\mathrm{XRD}$ patterns of pure $\mathrm{NiO}$ and support $\mathrm{C}$ has been also included.

To corroborate the effect of supports on the morphology and distribution of supported nickel oxide particles, samples with a 50 wt.\% NiO-loading were further analysed by TEM and EDX (Figure 4). When $\mathrm{NiO}$ is supported on unmodified PCH siliceous support (Support A), nickel oxide particles (detected by selected-area electron diffraction) with size in the range 5-30 $\mathrm{nm}$ are observed (Figure 4,50Ni/A). On the other hand, if the active phase is deposited on $\mathrm{PCH}$ with low and intermediate $\mathrm{Nb}$ contents (5 and $15 \mathrm{wt} . \%$ $\mathrm{Nb}_{2} \mathrm{O}_{5}$; Support $\mathrm{B}$ and $\mathrm{C}$, respectively), $\mathrm{NiO}$ particle size decreases down to 5-20 $\mathrm{nm}$ for $50 \mathrm{Ni} / \mathrm{B}$ and 3-10 $\mathrm{nm}$ for $50 \mathrm{Ni} / \mathrm{C}$ catalyst (Figure 4). In all cases, EDX analyses show a good dispersion of $\mathrm{NiO}$ along the support in these three catalysts. In contrast, when the amount of $\mathrm{Nb}$ deposited on $\mathrm{PCH}$ is increased up to $30 \mathrm{wt} \% \mathrm{Nb}_{2} \mathrm{O}_{5}$ (Support D), the particle size of supported $\mathrm{NiO}$ particles increases, falling in the range 20-40 nm (Figure 4, 50Ni/D). This confirms that, low/intermediate Nb-loadings on $\mathrm{PCH}$ favour a smaller particle size of $\mathrm{NiO}$. 
Figure 4. TEM images and their corresponding EDX maps of supported $\mathrm{NiO}$ catalysts with $50 \mathrm{wt} \%$ of $\mathrm{NiO}: 50 \mathrm{NiO} / \mathrm{A} ; 50 \mathrm{NiO} / \mathrm{B} ; 50 \mathrm{NiO} / \mathrm{C}$; and $50 \mathrm{NiO} / \mathrm{D}$.

Supported catalysts (with a 50 wt.\% NiO) were also characterized by Raman spectroscopy (Figure 5). The samples were irradiated with an UV-laser (325 nm), since conventional Raman experiments conducted using a $514 \mathrm{~nm}$ radiation source resulted in extremely noisy spectra, masked by Raman fluorescence phenomena. Interestingly, UV-Raman spectroscopy has been reported to be more sensitive to the surface region of solid materials, ${ }^{[40,41]}$ what makes it more suitable to study solid catalysts. All the spectra display four Raman bands that can be unambiguously assigned to NiO. These signals correspond to one-phonon (1P) TO (transverse optical) and LO (longitudinal optical) modes (at $\sim 570 \mathrm{~cm}^{-1}$ ), two-phonon (2P) $2 \mathrm{TO}$ modes (at $730 \mathrm{~cm}^{-1}$ ), TO $+\mathrm{LO}$ (at $\sim 906$ $\left.\mathrm{cm}^{-1}\right)$ and 2LO (at $\left.\sim 1090 \mathrm{~cm}^{-1}\right)$ modes (Figure 5). ${ }^{[42,43]}$

Figure 5. UV-Raman spectra of UV-Raman spectra of supported $\mathrm{NiO}$ catalysts with 50 wt $\%$ of $\mathrm{NiO}: 50 \mathrm{NiO} / \mathrm{A} ; 50 \mathrm{NiO} / \mathrm{B} ; 50 \mathrm{NiO} / \mathrm{C}$; and $50 \mathrm{NiO} / \mathrm{D}$.

The disorder-induced $1 \mathrm{P}$ (LO) band at $\sim 570 \mathrm{~cm}^{-1}$ presents low intensity when $\mathrm{NiO}$ is supported on PCH (Figure 5, 50Ni/A). Interestingly, the relative intensity of 1P (LO) band increases for $50 \mathrm{NiO} / \mathrm{B}$ and $50 \mathrm{Ni} / \mathrm{C}$, i.e. at intermediate $\mathrm{Nb}$-loadings on $\mathrm{PCH}(5$ and 15 wt.\% $\mathrm{Nb}_{2} \mathrm{O}_{5}$ ) (Figure 5). Conversely, at higher $\mathrm{Nb}$ contents on the support (30 30 wt.\% $\mathrm{Nb}_{2} \mathrm{O}_{5}$, Support D), the intensity of $2 \mathrm{P}$ modes of $\mathrm{NiO}$ increases notably (Figure 5, $50 \mathrm{Ni} / \mathrm{D})$. These spectral features can be explained in terms of $\mathrm{NiO}$ particle size. This way, the relative intensity of $1 \mathrm{P}$ band will increase concomitantly with: i) the decrease of $\mathrm{NiO}$ 
particle size and; ii) the presence of defects. It is worth mentioning that the most selective catalysts in the ODH of ethane (as it will be discussed later) show the highest relative intensity of LO (1P) Raman band. This could indicate a relationship between selectivity to ethylene in the ODH of ethane and particle size and/or concentration of defects, as it was previously suggested in literature. ${ }^{[30]}$

The effect of NiO-loading and type of support on the reducibility of supported $\mathrm{NiO}$ catalysts was studied by means of temperature-programmed reduction $\left(\mathrm{TPR}-\mathrm{H}_{2}\right)($ Figure 6). $\mathrm{H}_{2}$ up-takes measured during the experiments correspond to the reduction of $\mathrm{NiO}$ theoretical amounts added in each catalyst (Table 2).

Figure 6a displays $\mathrm{TPR}-\mathrm{H}_{2}$ profiles of $\mathrm{NiO}$ supported on $\mathrm{PCH}$ with a 15 wt. $\% \mathrm{Nb}_{2} \mathrm{O}_{5}$ (Support C). Unmodified $\mathrm{NiO}$ presents its main reduction peak at ca. $296^{\circ} \mathrm{C}$, showing a shoulder at $315^{\circ} \mathrm{C}$, which is the typical reduction profile of bulk NiO. ${ }^{[29,30]}$ It can be seen that increasing NiO-loading on Support C, leads to a shift of the main reduction peak towards lower temperatures, indicating an increased reducibility (Figure 6a).

If we compare TPR- $\mathrm{H}_{2}$ profiles at a fixed 50 wt. $\%$ NiO-loading, it can be found that, regardless of the support used, the catalysts present a lower reducibility than bulk $\mathrm{NiO}$, displaying their maximum $\mathrm{H}_{2}$ consumption in the range $350-380{ }^{\circ} \mathrm{C}$ (Figure 6b). Despite this, $50 \mathrm{Ni} / \mathrm{C}$ catalyst shows a slightly lower reducibility than the rest of materials (reduction peak centred at $375^{\circ} \mathrm{C}$ ), which in addition presents the smallest $\mathrm{NiO}$ particle size (Figure 6b, 50Ni/C).

Figure 6. TPR- $\mathrm{H}_{2}$ profiles of: a) Supported $\mathrm{NiO}$ catalysts, using Support C (i.e. with 15 wt. $\% \mathrm{Nb}_{2} \mathrm{O}_{5}$ on $\mathrm{PCH}$ ); b) supported $\mathrm{NiO}$ catalysts with $50 \mathrm{wt} \%$ of $\mathrm{NiO}$. 
To evaluate the effect of $\mathrm{Nb}$-containing supports on the nature of surface $\mathrm{Ni}$ species, catalysts with a 50 wt.\% NiO were studied by XPS. Figure 7 shows Ni $2 p$ core-level spectra of $50 \mathrm{wt} . \% \mathrm{NiO}$ supported catalysts, using supports with increasing $\mathrm{Nb}$-loadings $\left(0,5,15,30\right.$ wt. $\% \mathrm{Nb}_{2} \mathrm{O}_{5}$ on $\mathrm{PCH}$, Supports $\mathrm{A}, \mathrm{B}, \mathrm{C}$ and D respectively). For comparison, $\mathrm{Ni} 2 p_{3 / 2}$ core-level spectra of $\mathrm{NiO} / \mathrm{Nb}_{2} \mathrm{O}_{5}$ and unsupported $\mathrm{NiO}$ are shown in Figure $\mathbf{S 3}$ (Supporting information). All the spectra display the typical features of Ni $2 p$ core level: i) a main peak at ca. $854-855 \mathrm{eV}$, assigned to $\mathrm{Ni}^{2+}$ surface species, and; ii) two satellite structures (Sat I and Sat II) (Figure 7). Sat I, located at ca. $1.5 \mathrm{eV}$ over the main peak, is attributed to different types of surface defects such as, $\mathrm{Ni}^{2+}$ vacancies, ${ }^{[44,45]}, \mathrm{Ni}^{2+}-\mathrm{OH}$ sites ${ }^{[46]}$ or the presence of $\mathrm{Ni}^{3+}$ species. ${ }^{[47]}$ Variations in the relative intensity of this peak have, in some cases, been ascribed to changes in $\mathrm{NiO}$ particle size. ${ }^{[45]}$ On the other hand, the appearance of Sat II structure at ca. $7 \mathrm{eV}$ over the main peak, is assigned to metal-ligand charge transfer. ${ }^{[44,46,48]}$ Although XPS spectral features are still under debate, the spectra show that, when $\mathrm{NiO}$ is supported on $\mathrm{Nb}$-containing supports, the relative intensity of Sat I peak increases, suggesting a higher active-phase support interaction (Figure 7).

Figure 7. Ni $2 p$ core-level spectra of supported NiO catalysts with $50 \mathrm{wt} \%$ of $\mathrm{NiO}$ : a) $50 \mathrm{NiO} / \mathrm{A}$; b) $50 \mathrm{NiO} / \mathrm{B}$; c) $50 \mathrm{NiO} / \mathrm{C}$; and d) $50 \mathrm{NiO} / \mathrm{D}$.

Since $\mathrm{Nb}$-containing siliceous porous clays heterostructures present an effective interaction with the active phase (i.e. they are able to modify structural and chemical characteristics of $\mathrm{NiO}$ ), we decided to study the chemical nature of surface $\mathrm{Nb}$ species in 50 wt. $\%$ NiO supported catalysts by XPS. Figure 8 presents Nb $3 d$ core-level XPS spectra of $\mathrm{NiO}$ supported catalysts. The spectra show differences depending on $\mathrm{Nb}$ content in the support. At relatively low $\mathrm{Nb}$ concentration on the support (5 and $15 \% \mathrm{Nb}$ ), the samples 
display a single $\mathrm{Nb} 3 d_{5 / 2}$ XPS peak centred at $207.9 \mathrm{eV}$, which can be assigned to anchored $\mathrm{Nb}^{5+}$ species (Figure 8, spectra $a$ and $b$, respectively). ${ }^{[36]}$ When increasing the amount of $\mathrm{Nb}$ incorporated on siliceous porous clays heterostructures, a new peak at lower binding energies (ca. $206.5 \mathrm{eV}$ ) appears in the spectra (Figure 8, spectra c), which can be assigned to $\mathrm{Nb}^{5+}$ in $\mathrm{Nb}_{2} \mathrm{O}_{5}{ }^{[37,38]}$

Figure 8. $\mathrm{Nb} 3 d$ core-level spectra of $\mathrm{Nb}$-containing supported $\mathrm{NiO}$ catalysts with 50 $\mathrm{wt} \%$ of $\mathrm{NiO}$ : a) $50 \mathrm{NiO} / \mathrm{B}$; b) $50 \mathrm{NiO} / \mathrm{C}$; and c) $50 \mathrm{NiO} / \mathrm{D}$.

On the other hand, diffuse reflectance UV-VIS spectra for the series of supported $\mathrm{NiO}$ catalysts with a 50 wt. $\% \mathrm{NiO}$ loading show similar features than those observed on the $\mathrm{Nb}$-containing supports: i) a red shift in the absorption edge when $\mathrm{Nb}$-content in the support increases (Figure S4, Supporting information); and ii) an increase in the Egap value when $\mathrm{NiO}$ is supported on $\mathrm{Nb}$-containing $\mathrm{PCH}$ (Table 1 and Figure $\mathbf{S 5}$ in Supporting information).

In summary, spectroscopic analysis of supports and catalysts, show that two types of $\mathrm{Nb}$ species can exist in the catalysts: i) well-dispersed $\mathrm{Nb}^{5+}$ species at low $\mathrm{Nb}$-loadings on $\mathrm{PCH}$, which are able to substantially modify $\mathrm{NiO}$ (particle size, number of defects, etc.) and, ii) $\mathrm{Nb}^{5+}$ sites similar to those observed in $\mathrm{Nb}_{2} \mathrm{O}_{5}$ (appearing at high $\mathrm{Nb}$-loadings on the support). The use of $\mathrm{Nb}$-containing $\mathrm{PCH}$ as supports for $\mathrm{NiO}$ improves the dispersion of $\mathrm{NiO}$ in comparison with unmodified $\mathrm{PCH}$ and $\mathrm{Nb}_{2} \mathrm{O}_{5}$.

\section{Catalytic results in the ODH of ethane}


According to the changes in the chemical nature of $\mathrm{NiO}$ induced by the different supports (particle size, reducibility, concentration of defects...), NiO-containing catalysts were tested as catalysts for the oxidative dehydrogenation (ODH) of ethane (Table 3). During the catalytic tests, the only reaction products observed were ethylene and $\mathrm{CO}_{2}$. Traces of CO cannot be discarded, although, if present, the selectivity should be lower than $1 \%$.

Figure 9a compares the catalytic activity (in $\mathrm{g}_{\mathrm{C} 2} \mathrm{~kg}_{\mathrm{cat}}{ }^{-1} \mathrm{~h}^{-1}$ ) of $\mathrm{xNiO} / \mathrm{C}$ series with different $\mathrm{NiO}$ contents. It can be observed that catalytic activity increases with the NiOloading until 50 wt.\% $\mathrm{NiO}$ (Figure 9a). For higher NiO loadings the catalytic activity is kept rather stable. However, if the activity per gram of $\mathrm{NiO}$ is considered, there exists a clear maximum at $50 \mathrm{wt} . \% \mathrm{NiO}$ (Table 3).

We have also compared the activity of $50 \mathrm{wt} . \% \mathrm{NiO}$ catalysts supported on $\mathrm{PCH}$ with increasing Nb-loading (Supports A-D with 0 to $30 \mathrm{wt} . \% \mathrm{Nb}_{2} \mathrm{O}_{5}$ ). The catalytic results are shown in Figure 9b. In this case, the activity increases with the $\mathrm{Nb}$ content until reaching a maximum at 15 wt. $\% \mathrm{Nb}_{2} \mathrm{O}_{5}(50 \mathrm{Ni} / \mathrm{C})$ (Table 3). Further increasing Nb-loading in the support (i.e. Support D, with $30 \mathrm{wt} . \% \mathrm{Nb}_{2} \mathrm{O}_{5}$ ) leads to a decrease in the catalytic activity.

Figure 9. Influence of $\mathrm{NiO}$ loading (for catalysts of $\mathrm{xNiO} / \mathrm{C}$ series) (a) and influence of $\mathrm{Nb}$-loading on support (for catalysts with $50 \mathrm{wt} \%$ of $\mathrm{NiO}$ ) (b) on catalytic activity (in $\mathrm{g}_{\mathrm{C} 2}$ $\mathrm{kg}_{\mathrm{cat}}{ }^{-1} \mathrm{~h}^{-1}$ ) during the ODH of ethane over supported NiO catalysts. Reaction conditions: $\mathrm{C}_{2} / \mathrm{O}_{2} / \mathrm{He}=3 / 1 / 26$ molar ratio, $\mathrm{T}=450^{\circ} \mathrm{C}$ and $\mathrm{W} / \mathrm{F}=4 \mathrm{~g}_{\text {cat }} \mathrm{h} \mathrm{mol}_{\mathrm{C} 2}{ }^{-1}$.

Provided that the differences in activity are not of orders of magnitude, the selectivity to ethylene is a more important factor to consider in order to determine the efficiency of this series of catalysts. Accordingly, the catalytic performance of supported $\mathrm{NiO}$ catalysts has 
been studied by using different contact times (i.e. varying catalyst weight or the total flow) and fixing reaction temperature and $\mathrm{C}_{2} / \mathrm{O}_{2} / \mathrm{He}$ ratio. This way, we can compare the selectivity to ethylene in the ODH of ethane at a given conversion.

Figure 10a displays the variation of ethylene selectivity with $\mathrm{NiO}$ content for $\mathrm{xNi} / \mathrm{C}$ series at isoconversion conditions (i.e. ethane conversion of $10 \%$ at $450{ }^{\circ} \mathrm{C}$ ). It can be noted that the selectivity to the olefin increases concomitantly with NiO-loading, reaching the maximum at 50 wt. $\% \mathrm{NiO}$ (catalyst $50 \mathrm{Ni} / \mathrm{C}$; $\mathrm{S}_{\text {ethylene }}=87 \%$ ). Higher NiO loadings led to a decrease in the selectivity to ethylene.

Figure 10. a) Variation of the selectivity to ethylene as a function of NiO-loading on Support C (15 wt.\% $\mathrm{Nb}_{2} \mathrm{O}_{5}$ on $\mathrm{PCH}$. b) Variation of the selectivity to ethylene as a function of ethane conversion for supported $50 \mathrm{wt} . \% \mathrm{NiO}$ catalysts. Reaction conditions as in Fig. 9.

We have also analysed the catalytic behaviour $50 \mathrm{wt} . \% \mathrm{NiO}$ catalysts supported over PCHs materials with increasing Nb-loading (Supports A-D). Figure 10b shows the variation of the selectivity to ethylene in the ODH of ethane as a function of ethane conversion for $50 \mathrm{wt} . \% \mathrm{NiO}$ catalysts at $450{ }^{\circ} \mathrm{C}$. It is worth mentioning that, regardless of the nature of the catalysts, the selectivity to ethylene barely varies with ethane conversion under the reaction condition applied in the study. This means that, even for the less selective materials, the deep oxidation of the olefin to carbon oxides does not take place, i.e. carbon oxides are essentially formed directly from ethane. ${ }^{[49]}$

Despite this, variations in the selectivity to ethylene in the ODH of ethane are observed depending on the nature of the support (Figure 10b). When $\mathrm{NiO}$ is supported on 
unmodified PCH, a low selectivity to ethylene (of ca. $38 \%$ ) is achieved (Figure 10b, $50 \mathrm{Ni} / \mathrm{A}$ ). This selectivity lies in the range of that reached on bulk NiO (ca. $33 \%$ ) (Table 3), indicating that the unmodified PCH support is not able to provide an effective activephase support interaction. On the other hand, when $\mathrm{NiO}$ on a $\mathrm{PCH}$ support with $5 \mathrm{wt} . \%$ $\mathrm{Nb}_{2} \mathrm{O}_{5}$ (Support B), the selectivity to the olefin drastically increases, up to $67 \%$ (Figure $10 \mathbf{b}, 50 \mathrm{Ni} / \mathrm{B}$ ), which is slightly higher than the one achieved on the $\mathrm{Nb}_{2} \mathrm{O}_{5}$-supported catalyst (ca. $59 \%$ ) (Table 3). By increasing the amount of $\mathrm{Nb}$ deposited on $\mathrm{PCH}$ up to 15 wt. $\% \mathrm{Nb}_{2} \mathrm{O}_{5}$ (Support C), the selectivity to ethylene further increases, up to ca. $87 \%$, which is in the range of the best NiO-based catalysts reported in the literature (for instance, $\mathrm{Nb}$-doped $\mathrm{NiO}$ catalysts ${ }^{[13]}$ (Figure 10b, 50Ni/C). However, if higher amounts of $\mathrm{Nb}$ are deposited on $\mathrm{PCH}$ support (30 wt. $\% \mathrm{Nb}_{2} \mathrm{O}_{5}$, Support D), selectivity to ethylene drops down to ca. $64 \%$ (Figure 10b, 50Ni/D).

Then, it seems that the impregnation of an appropriate amount of $\mathrm{Nb}$ on a bentonitederived $\mathrm{PCH}$ material (and the subsequent addition of $\mathrm{NiO}$ ) leads to a drastic improvement in the selectivity to ethylene in the $\mathrm{ODH}$ of ethane, from ca. $38 \%(50 \mathrm{Ni} / \mathrm{A}$ catalyst, i.e. when using a $\mathrm{Nb}$-free support) to ca. $87 \%(50 \mathrm{Ni} / \mathrm{C}$ catalyst). Moreover, the use of a matrix such as the pillared clay to deposit niobium is necessary to obtain efficient catalysts. In this sense, the use of the $\mathrm{Nb}$-modified porous clay support leads to an improvement in the selectivity to ethylene from ca. $60 \%\left(50 \mathrm{Ni} / \mathrm{Nb}_{2} \mathrm{O}_{5}\right)$ to ca. $87 \%$ $(50 \mathrm{Ni} / \mathrm{C})$. Therefore, to achieve optimal results in the $\mathrm{ODH}$ of ethane, the presence of a high surface area material on which niobium oxide can be dispersed is necessary. Thereby, the absence of either niobium or $\mathrm{PCH}$ gives rise to an ineffective NiO-support interaction, leading to low ethylene selectivity (ca. 30-60 \%).

We want to mention that these catalytic results have been obtained using $\mathrm{C}_{2} / \mathrm{O}_{2}$ ratio of 3. However, the use of a feed richer in oxygen leads to a slight drop in the selectivity to 
ethylene. Then, over $50 \mathrm{Ni} / \mathrm{C}$ catalyst, using $\mathrm{W} / \mathrm{F}=2 \mathrm{~g}_{\mathrm{cat}} \mathrm{h} \operatorname{mol}_{\mathrm{C} 2}{ }^{-1}$ and a $\mathrm{C}_{2} / \mathrm{O}_{2}$ ratio of 1 $\left(\mathrm{C}_{2} / \mathrm{O}_{2} / \mathrm{He}=1 / 1 / 8\right.$ molar ratio $)$, the ethane conversion is $10.7 \%$ and the selectivity to ethylene is $82.3 \%$.

\section{Discussion}

In this study we have shown that by dispersing niobium on a high surface area porous clay heterostructure $(\mathrm{PCH})$ material, a suitable support for $\mathrm{NiO}$ can be synthesized. $\mathrm{NiO}$ catalysts supported on $\mathrm{Nb}$-containing $\mathrm{PCH}$ display an enhanced catalytic performance in the $\mathrm{ODH}$ of ethane, compared to formulations in the absence of $\mathrm{PCH}\left(\mathrm{NiO} / \mathrm{Nb}_{2} \mathrm{O}_{5}\right)^{[31]}$ or $\mathrm{Nb}$-free $\mathrm{PCH}(\mathrm{NiO} / \mathrm{PCH}$, this work). Interestingly, as it takes place in $\mathrm{Nb}$-promoted $\mathrm{NiO}$ catalysts, ${ }^{[13-16]}$ in our supported catalysts the Nb-loading should be controlled to optimize the catalytic results. Then, an appropriate amount of niobium must be deposited on the surface of the $\mathrm{PCH}$ matrix. Then, the optimal $\mathrm{Nb}$-loading corresponds to $15 \mathrm{wt} . \% \mathrm{Nb}_{2} \mathrm{O}_{5}$ (Support C). Lower or higher Nb-loadings on $\mathrm{PCH}$ support (5 or 30 wt.\% $\mathrm{Nb}_{2} \mathrm{O}_{5}$, respectively) lead to supported $\mathrm{NiO}$ catalysts presenting a lower ethylene formation in the ODH of ethane. Despite this, $\mathrm{NiO} / \mathrm{Nb}-\mathrm{PCH}$ materials display an improved catalytic behaviour (in terms of ethylene selectivity), with respect to $\mathrm{NiO}$ supported on $\mathrm{PCH}$ (sample $50 \mathrm{NiO} / \mathrm{A}$ ) or supported on $\mathrm{Nb}_{2} \mathrm{O}_{5}$ ( sample $50 \mathrm{Ni} / \mathrm{Nb}_{2} \mathrm{O}_{5}$ ).

For bulk $\mathrm{NiO}$ catalysts, $\mathrm{NiO}$ crystallite size has been demonstrated to play an important role in olefin formation in the $\mathrm{ODH}$ of ethane. ${ }^{[29,30]}$ By modifying the synthesis procedure (for instance, adding organic additives, ${ }^{[39]}$ or transition metal promoters ${ }^{[29]}$ ), it is possible to decrease $\mathrm{NiO}$ average crystallite size, what generally leads to higher ethylene selectivity. In the same way, the addition of low/intermediate amounts niobium on $\mathrm{PCH}$ support (0-15 wt.\% $\mathrm{Nb}_{2} \mathrm{O}_{5}$, Supports $\mathrm{B}$ and $\mathrm{C}$ ) favours a lower $\mathrm{NiO}$ crystallite size, an 
improved $\mathrm{NiO}$ dispersion and a higher selectivity to ethylene. On the contrary, higher $\mathrm{Nb}-$ loadings on $\mathrm{PCH}$ (30 wt.\% $\mathrm{Nb}_{2} \mathrm{O}_{5}$, Support D) give rise to bigger $\mathrm{NiO}$ particles and a decrease in ethylene selectivity.

Figure S6A shows the variation of ethylene selectivity (measured at isoconversion conditions, $10 \%$ ethane conversion) as a function of $\mathrm{NiO}$ crystallite size for all synthesized materials. For $\mathrm{Nb}$-containing catalysts, the selectivity follows a quite defined trend, in a way that the lower the $\mathrm{NiO}$ crystallite size, the higher the selectivity to ethylene. However, selectivity levels for $\mathrm{Nb}$-free catalysts are far below the levels that would correspond to the same $\mathrm{NiO}$ crystallite size in Nb-containing catalysts. These observations suggest that other factors (apart from the particle size) have to be taken into consideration to explain the catalytic performance of these materials (such as reducibility, nature of surface $\mathrm{Ni}$ sites or $\mathrm{NiO}$-support interaction),

The reducibility of nickel oxide species can have some influence on the selectivity to ethylene achieved. ${ }^{[13-29,31]}$ Since reducibility is not a parameter easy to be quantified, we have selected the temperature for the maxima of the main TPR peak as a reference value. This way, the higher the reduction temperature, the lower the reducibility of $\mathrm{Ni}^{\mathrm{n}+}$ sites on the catalyst. Figure S6B (supporting information) shows the variation of the selectivity to ethylene measured at isoconversion conditions (10\% ethane conversion) as a function of the maximum $\mathrm{H}_{2}$-consumption temperature in $\mathrm{H}_{2}$-TPR profiles for each NiO-based catalyst. It can be seen that the most selective catalysts are those with the lowest reducibility. This suggests that highly reducible nickel oxide species are prone to activate ethane in a non-selective way, thus directing the reaction towards total oxidation, rather than to oxidative dehydrogenation. ${ }^{[26]}$ 
Characterization results of supports and supported $\mathrm{NiO}$ catalysts indicate that we can have two different types of $\mathrm{Nb}$ sites with different chemical nature: i) $\mathrm{Nb}^{5+}$ site that are well anchored to $\mathrm{PCH}$ support and, ii) $\mathrm{Nb}^{5+}$ species similar to those found in $\mathrm{Nb}_{2} \mathrm{O}_{5}$. Depending on the type of $\mathrm{Nb}$ on the support, variations in $\mathrm{NiO}$-support interaction will take place, thus giving rise to different $\mathrm{NiO}$ particles showing a different selectivity to ethylene in the ODH of ethane.

Interestingly, the relative intensity of Sat I peak in the XPS spectra slightly increases with respect to the main peak when $\mathrm{Nb}$ is incorporated in the $\mathrm{PCH}$ support, concomitantly with the increase in the selectivity to ethylene in the $\mathrm{ODH}$ of ethane (Figure 7). This fact suggests that the support does not exclusively modulates $\mathrm{NiO}$ particle size, but also modifies the concentration of defects in the active phase, like $\mathrm{Ni}^{3+}, \mathrm{Ni}^{2+}$ vacancies or $\mathrm{Ni}^{2+}$ $\mathrm{OH}$ surface sites, which can play a key role in the catalytic behaviour. For example, the presence of $\mathrm{Ni}^{3+}$ species has been linked with a higher concentration of electrophilic oxygen species, responsible for total oxidation. ${ }^{[50]}$

On the other hand, Ni $2 p$ XPS spectra of the less selective catalysts, i.e. $50 \mathrm{NiO} / \mathrm{A}$ (Figure 7, spectra a), $\mathrm{NiO} / \mathrm{Nb}_{2} \mathrm{O}_{5}$ (Figure S2, spectra a; Supporting information) and unsupported $\mathrm{NiO}$ (Figure S2, spectra b; Supporting information), display high similarities, particularly a low Sat I/Main peak ratio. Accordingly, it seems that these supports are not able to interact efficiently with $\mathrm{NiO}$, leading to similar $\mathrm{Ni}^{\mathrm{n}+}$ surface sites and, subsequently, to a low selectivity to ethylene in the ODH of ethane (ca. 30-60\%).

We must underline that supports used (unmodified $\mathrm{PCH}$ or $\mathrm{Nb}$-containing $\mathrm{PCH}$ ) show a negligible conversion of ethane under the reaction conditions used in this study. Therefore, the reactivity is completely determined by the catalytic potential of the nickel oxide. In the case of $\mathrm{Nb}$-free $50 \mathrm{Ni} / \mathrm{A}$ catalyst, $\mathrm{NiO}$-support interactions will be dominated 
by NiO-silica contact, which is not able to modify the chemical nature of NiO. ${ }^{[30]}$ Thus, a low selectivity to ethylene in the ODH of ethane is achieved (ca. $30 \%$, similar to that observed for unsupported $\mathrm{NiO}$ ). In the same line, $50 \mathrm{NiO} / \mathrm{Nb}_{2} \mathrm{O}_{5}$ does not interacts efficiently with $\mathrm{NiO}$, leading to low $\mathrm{NiO}$ dispersion and large $\mathrm{NiO}$ particles similar to those in non-selective $\mathrm{NiO} \cdot{ }^{[31]}$ On the contrary, when $\mathrm{NiO}$ is supported on $\mathrm{Nb}$ containing $\mathrm{PCH}$ materials, a drastic increase in the selectivity to ethylene is observed (up to $87 \%$ for $50 \mathrm{Ni} / \mathrm{C}$ catalyst). Unlike in the case of $\mathrm{Nb}_{2} \mathrm{O}_{5}, \mathrm{Nb}$ species present on these supports are able to interact in an efficient way with $\mathrm{NiO}$. The efficiency of this active phase-support interaction will depend fundamentally on the amount of $\mathrm{Nb}$ loaded in on the porous clay heterostructure.

At low Nb-loadings ( $5 \mathrm{wt} . \% \mathrm{Nb}_{2} \mathrm{O}_{5}$ on $\mathrm{PCH}, 50 \mathrm{Ni} / \mathrm{B}$ catalyst), at which the optimum $\mathrm{Nb}$ coverage is not achieved, the support presents two main regions susceptible to interact with NiO: i) dispersed $\mathrm{Nb}^{5+}$ surface sites and; ii) uncovered PCH silica-rich zones. The interaction between well-anchored $\mathrm{Nb}^{5+}$ sites leads to selective sites in the ODH of ethane, whereas interaction between $\mathrm{NiO}$ and $\mathrm{SiO}_{2}$ zones on $\mathrm{PCH}$ gives rise to unselective sites (similar to those found in unsupported $\mathrm{NiO}$ ). Then, for $50 \mathrm{Ni} / \mathrm{B}$ sample ( $5 \mathrm{wt} . \%$ $\mathrm{Nb}_{2} \mathrm{O}_{5}$ on $\mathrm{PCH}$ ), higher selectivity to ethylene is observed (ca. $67 \%$ ), in comparison with PCH-supported catalysts (50Ni/A, presenting a selectivity to ethylene of $38 \%$ ). Consequently, it is possible to optimize the catalytic performance of this system by incorporating increasing amounts of $\mathrm{Nb}$ on the support. This way, when using a $15 \mathrm{wt} . \%$ $\mathrm{Nb} \mathrm{PCH}$ support for $\mathrm{NiO}(50 \mathrm{Ni} / \mathrm{C}$ catalyst $)$ we are favouring the desired $\mathrm{Nb}^{5+}-\mathrm{NiO}$ interaction, minimizing the exposure silica zones on the support, thus achieving a high selectivity to ethylene in the ODH of ethane (ca. $87 \%$ ). However, if relatively high amounts of $\mathrm{Nb}$ are deposited on $\mathrm{PCH}$ support (30 wt. $\% \mathrm{Nb}_{2} \mathrm{O}_{5}$ on $\mathrm{PCH}, 50 \mathrm{Ni} / \mathrm{D}$ catalyst), 
the segregation of bulk $\mathrm{Nb}_{2} \mathrm{O}_{5}$ can take place, leading to bigger $\mathrm{NiO}$ particles, a lower dispersion of the active phase, and a decrease of the selectivity to the olefin (ca. $64 \%$ ).

One of the main problems of the Nb-promoted $\mathrm{NiO}$ catalysts is their lack of stability with the time on stream. This instability has been related to the formation of the less active $\mathrm{NiNb}_{2} \mathrm{O}_{6}$ phase ${ }^{[13,16]}$ and the reduction of the amount of active oxygen in $\mathrm{NiO}^{[16-21]}$ and

to a decrease in the surface area. ${ }^{[16,51]}$ We have wanted to check if our supported catalysts also present that instable behaviour. After $8 \mathrm{~h}$ on line, $50 \mathrm{Ni} / \mathrm{C}$ catalyst presented a slight decrease of the ethane conversion (Figure S7, Supporting information) together with a slight increase in the ethylene selectivity. A further study for longer times would be required to determine the industrial applicability of these materials.

\section{Conclusions}

In summary, it has been proven that it is possible to prepare efficient supported $\mathrm{NiO}$ catalysts for the $\mathrm{ODH}$ of ethane, by using $\mathrm{Nb}$-modified porous clay heterostructures $(\mathrm{Nb}$ $\mathrm{PCH}$ ) as supports. $\mathrm{NiO}$ catalysts supported on $\mathrm{Nb}-\mathrm{PCH}$ materials present an enhanced selectivity to ethylene (up to ca. $90 \%$ ) with respect to $\mathrm{PCH}$ - and $\mathrm{Nb}_{2} \mathrm{O}_{5}$-supported nickel oxide catalysts, which shows a selectivity to ethylene of ca. 30 and $60 \%$, respectively).

While $\mathrm{Nb}_{2} \mathrm{O}_{5}$ and unmodified $\mathrm{PCH}$ do not modify the chemical nature of $\mathrm{NiO}, \mathrm{Nb}$ containing $\mathrm{PCH}$ supports are able to: i) decrease $\mathrm{NiO}$ particle size; ii) induce changes on $\mathrm{Ni}^{\mathrm{n+}}$ surface sites and; iii) decrease the reducibility of $\mathrm{Ni}^{\mathrm{n}+}$ species. According to catalytic results, the key factor to achieve a high selectivity to ethylene in the $\mathrm{ODH}$ of ethane is to control NiO-support interaction. This can be achieved by controlling Nb-loading on the support. Thus, Nb-loadings of $15 \mathrm{wt} . \% \mathrm{Nb}_{2} \mathrm{O}_{5}$ deposited on $\mathrm{PCH}$ minimize non-selective silica zones exposed on the surface, thus leading to an ethylene selectivity values in the range of the best catalysts reported in the literature. 
Characterization of $\mathrm{Nb}$-containing supports and catalysts demonstrate that $\mathrm{Nb}^{5+}$ species on $\mathrm{PCH}$ present a different chemical nature than that observed in $\mathrm{Nb}_{2} \mathrm{O}_{5}$. Specifically, XRD, XPS and UV-VIS results suggest that $\mathrm{Nb}^{5+}$ species are dispersed and well-anchored on $\mathrm{PCH}$ surface. These species are able to interact efficiently with $\mathrm{NiO}$, giving rise to an excellent catalytic performance in the $\mathrm{ODH}$ of ethane, which is not the case of $\mathrm{Nb}^{5+}$ sites in $\mathrm{Nb}_{2} \mathrm{O}_{5}$.

\section{Experimental Section}

\section{Preparation of Supports and catalysts}

A bentonite from "Sierra de Níjar" (Spain) supplied by Minas de Gador S. A. was used as the raw material. The bentonite presents a high proportion of montmorillonite as reported in previous studies. ${ }^{[26]}$ Prior to the synthesis, montmorillonite phase was collected by sedimentation and treated with a solution of $\mathrm{NaCl}$ for 1 day to obtain the homoionic montmorillonite (Na-mont). More details of the preparation are shown elsewhere. ${ }^{[26]}$ Si-pillars were then dispersed in an n-propanol solution with a ratio $\mathrm{Si} / \mathrm{n}$ propanol $=1$ and added to the previous suspension, and stirring for 3 days. The source of silicon used was tetraethyl orthosilicate (Aldrich). Then, the gel was filtered and washed with water and ethanol and dried at $60{ }^{\circ} \mathrm{C}$ in air for $12 \mathrm{~h}$. Finally the surfactant was removed by calcination in air at $550{ }^{\circ} \mathrm{C}$ for $6 \mathrm{~h}$. Thus, the sample with Si-pillars, a siliceous porous clay heterostructure $(\mathrm{PCH})$, was named as support A.

$\mathrm{Nb}$-containing siliceous porous clay heterostructure were prepared by adding solutions of niobium oxalate monooxalate adduct, i.e. $\mathrm{C}_{10} \mathrm{H}_{5} \mathrm{NbO}_{20}$ (ABCR), to the $\mathrm{PCH}$ support. After evaporation under vigorous stirring the paste obtained was dried at $120^{\circ} \mathrm{C}$ overnight 
and then calcined at $500^{\circ} \mathrm{C}$ for $2 \mathrm{~h}$ in static air. Thus, $\mathrm{Nb}$-containing supports have been named as $\mathrm{B}, \mathrm{C}$ or $\mathrm{D}$ for samples with a $\mathrm{Nb}$ content of 5,15 , or $30 \mathrm{wt} . \%$, respectively. The characteristics of supports are shown in Table 1.

Supported NiO catalysts were synthesized as follows: an ethanolic solution of nickel(II) nitrate $\mathrm{Ni}\left(\mathrm{NO}_{3}\right)_{2} \cdot 6 \mathrm{H}_{2} \mathrm{O}$ and oxalic acid (both from Sigma-Aldrich) was prepared (oxalic acid/Ni molar ratio of 3 ). To this mixture a porous clay heterostructure $(\mathrm{PCH})$ derived from bentonite with or without niobium (samples A, B, C or D) was added. After evaporation in a hot plate stirrer and drying at $120^{\circ} \mathrm{C}$ overnight, the catalysts were calcined at $500^{\circ} \mathrm{C}$ for $2 \mathrm{~h}$ in static air. The catalysts have been named as $\mathrm{xNi} /$ support (support $=\mathrm{A}, \mathrm{B}, \mathrm{C}$ or $\mathrm{D}$ ), $\mathrm{x}$ being the $\mathrm{NiO} \mathrm{wt} \%$ content. For example, the catalyst $50 \mathrm{Ni} / \mathrm{C}$ contains $50 \mathrm{wt} . \% \mathrm{NiO}$, the support consisting of $15 \mathrm{wt} . \% \mathrm{Nb}_{2} \mathrm{O}_{5}$ deposited on $\mathrm{BG}$ (sample C).

Diluted $\mathrm{NiO} / \mathrm{Nb}_{2} \mathrm{O}_{5}$ catalysts were synthesized as follows: an ethanolic solution of nickel nitrate $\mathrm{Ni}\left(\mathrm{NO}_{3}\right)_{2} \bullet 6 \mathrm{H}_{2} \mathrm{O}$ and oxalic acid (both from Sigma-Aldrich) was prepared (oxalic acid/Ni molar ratio of 3). To this mixture niobium oxide (hydrothermally synthesized, see

reference $^{[31]} ; \mathrm{S}_{\mathrm{BET}}=70 \mathrm{~m}^{2} \mathrm{~g}^{-1}$ ) was added. Then the mixture was vigorously stirred at $60^{\circ} \mathrm{C}$ until a paste was achieved. This material was introduced in a furnace and kept at $120{ }^{\circ} \mathrm{C}$ overnight and then was heat-treated in static air for $2 \mathrm{~h}$ at $500{ }^{\circ} \mathrm{C}$. The catalysts have been named as $50 \mathrm{NiO} / \mathrm{Nb}_{2} \mathrm{O}_{5}$ (i.e. $50 \mathrm{wt} \%$ content of $\mathrm{NiO}$ ). The characteristics of catalysts are shown in Table 2.

\section{Characterization}

Powder X-ray diffraction patterns were recorded in a powder diffractometer model D8 Avance A25 Bruker brand with a CuKa source operated at $40 \mathrm{kV}$ and $40 \mathrm{~mA}$. 
Transmission electron microscopy (TEM) images, selected-area electron diffraction (SAED) patterns and Energy-dispersive X-ray spectroscopy (EDX) maps were collected in a field-emission gun TECNAI G2 F20 S-TWIN electron microscope, operating at 200 $\mathrm{kV}$. Samples were sonicated in ethanol and deposited on a copper grid prior to analysis.

$\mathrm{N}_{2}$-adsorption isotherms were recorded in a Micromeritics ASAP 2000 device. The materials were degassed in vacuum at $300{ }^{\circ} \mathrm{C}$ prior to $\mathrm{N}_{2}$ adsorption. Surface areas were estimated by the Brunauer-Emmet-Teller (BET) method.

Raman spectroscopy was carried out in an inVia Renishaw spectrometer equipped with an Olympus microscope, at an exciting wavelength of $325 \mathrm{~nm}$.

Temperature-programmed reduction in $\mathrm{H}_{2}\left(\mathrm{TPR}-\mathrm{H}_{2}\right)$ was carried out in a Micromeritics Autochem 2190 instrument, equipped with a thermal conductivity detector (TCD). Samples were heated up to $800{ }^{\circ} \mathrm{C}$ (heating rate of $10{ }^{\circ} \mathrm{C} \mathrm{min}^{-1}$ ) using a reductive mixture

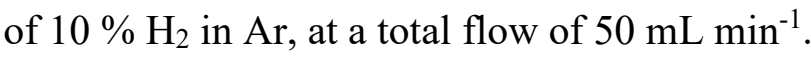

XPS measurements were carried on a Physical Electronics spectrometer (PHI Versa Probe II Scanning XPS Microprobe with monochromatic X-ray Al K $\alpha$ radiation $(100 \mu \mathrm{m}$, $100 \mathrm{~W}, 20 \mathrm{kV}, 1486.6 \mathrm{eV}$ ) and a dual-beam charge neutralizer. The spectrometer was calibrated with $\mathrm{Au} 4 f_{7 / 2}, \mathrm{Ag} 3 d_{5 / 2}$ and $\mathrm{Cu} 2 p_{3 / 2}$ photoelectron lines at 84.0, 368.2 and 932.7 $\mathrm{eV}$, respectively. The Au $4 f_{7 / 2}$ line was recorded with $0.73 \mathrm{eV} \mathrm{FWHM}$ at a binding energy (BE) of $84.0 \mathrm{eV}$, under a constant pass energy mode at $23.5 \mathrm{eV}$ condition. XPS spectra were analysed using PHI SmartSoft software and processed using MultiPak 9.3 package. The binding energy values for the measured spectra were referenced to $\mathrm{C} 1 \mathrm{~s}$ signal of adventitious carbon at $284.8 \mathrm{eV}$. Recorded spectra were fitted using Gauss-Lorentz curves. Atomic concentration percentages of the constituent elements of the surfaces were 
determined taking into account the corresponding area sensitivity factor for the different measured spectral regions.

Diffuse-reflectance UV-VIS spectra were recorded in a Cary 5000 spectrophotometer, in the $200-800 \mathrm{~nm}$ wavelength range.

\section{Catalytic tests for ethane ODH}

The catalytic experiments were carried out under steady state conditions using a fixedbed quartz tubular reactor working at atmospheric pressure. ${ }^{[26]}$ The flow rate $(25-100 \mathrm{ml}$ $\left.\mathrm{min}^{-1}\right)$ and the amount of catalyst $(0.1-0.3 \mathrm{~g}, 0.3-0.5 \mathrm{~mm}$ particle size) were varied in order to achieve different ethane conversion levels at a given reaction temperature. The feed consisted of a mixture of ethane/oxygen/helium with molar ratio of 3/1/26. Experiments were carried out in the $350-450{ }^{\circ} \mathrm{C}$ temperature range. Reactants and reaction products were analysed by on-line gas chromatography, using two packed columns: ${ }^{[26]}$ (i) Porapak Q (3 m); and ii) molecular sieve $5 \AA$ (2.5 m).

\section{Acknowledgements}

The authors would like to acknowledge the DGICYT in Spain (CRT12018-099668-BC21, RT12018-099668-B-C22 and MAT2017-84118-C2-1-R projects). Authors from ITQ also thank Project SEV-2016-0683 for supporting this research. D.D. thanks MINECO and Severo Ochoa Excellence Program for his fellowship (SVP-2014-068669).

\section{References}

[1] L. Nichols, Industry Perspectives: Global petrochemical sector to see robust growth to 2020, Hydrocarbon Processing 2017. March. 
[2] L. Hermabessiere, A. DehautaIk, P. Pont, C. Lacroix, R. Jezequel, P. Soudant, G. Duflos, Chemosphere 2017, 182, 781-793.

[3] L. Jia, S. Evans, S. van der Linden, Nature 2019, 4582.

[4] M. Ghanta, D. Fahey, B. Subramaniam, Appl. Petrochem. Res. 2014, 4, 167-179.

[5] T. Ren, M.K. Patel, K. Blok, Energy 2006, 31, 425-451.

[6] T. Ren, M.K. Patel, K. Blok, Energy 2008, 33, 817-833.

[7] F. Cavani, N. Ballarini, A. Cericola, Cat. Today 2007, 127, 113-131.

[8] J.M. López Nieto and B. Solsona in Metal Oxides in Heterogeneous Catalysis (Eds. J.C. Vedrine), Elsevier, 2018, pp. 211-286

[9] Ch. A Gärtner, A. C. van Veen, J.A. Lercher, ChemCatChem 2013, 5, 3196-3217.

[10] J.M. López Nieto, P. Botella, M.I. Vazquez, A. Dejoz, Chem. Commun. 2002, 17, 1906-1907

[11] B. Solsona, M.I. Vázquez, F. Ivars, A. Dejoz, P. Concepción, J.M. López Nieto, J. Catal. 2007, 252, 271-280.

[12] Y. Liu, Patent US6355854 B1, 2001.

[13] E. Heracleous, A.A. Lemonidou, J. Catal. 2006, 237, 162-174.

[14] E. Heracleous, A.A. Lemonidou, J. Catal. 2010, 270, 67-75.

[15] F. Skoufa, E. Heracleous, A.A. Lemonidou, J. Catal. 2015, 322, 118-129.

[16] B. Savova, S. Loridant, D. Filkova, J.M.M. Millet, Appl. Catal. A Gen. 2010, 390, 148-157.

[17] Z. Skoufa, E. Heracleous, A.A. Lemonidou, Catal. Today 2012, 192, 169-176.

[18] H. Zhu, S. Ould-Chikh, D.H. Anjum, M. Sun, G. Biausque, J.-M. Basset, V. Caps, J. Catal. 2012, 285, 292-303.

[19] B. Solsona, J.M. López Nieto, P. Concepcion, A. Dejoz, F. Ivars, M.I. Vazquez, J. Catal. 2011, 280, 28-39. 
[20] J.M. López Nieto, B. Solsona, R.K. Grasselli, P. Concepcion, Top. Catal. 2014, 57, 1248-1255.

[21] H. Zhu, D.C. Rosenfeld, M. Harb, D.H. Anjum, M.N. Hedhili, S. Ould-Chikh, J.M. Basset, ACS Catal. 2016, 6, 2852-2866.

[22] a) H. Zhu, H. Dong, P. Laveille, Y. Saih, V. Caps, J.M. Basset, Catal. Today 2014, 228, 58-64; b) H. Zhu, D.C. Rosenfeld, D.H. Anjum, S.S. Sangaru, Y. Saih, S. Ould-Chikh, J.M. Basset, J. Catal. 2015, 329, 291-306

[23] E. Heracleous, A. F. Lee, K. Wilson, A. A. Lemonidou, J. Catal. 2005, 231,159171.

[24] a) Zh. Zhang, J. Ding, R. Chai, G. Zhao, Y. Liu, Y. Lu, Appl. Catal. A: Gen 550 (2018) 151-159; b) Z. Zhang, G. Zhao, R. Chai, Z. Jian, Y. Liu, Y. Lu, Catal. Sci. Technol. 2018, 8, 4383-4389.

[25] Z. Skoufa, E. Heracleous, A. A. Lemonidou, J. Catal. 2015, 322, 118-129.

[26] B. Solsona, P. Concepción, J. M. López Nieto, A. Dejoz, J. A. Cecilia, S. Agouram, M. D. Soriano, V. Torres, J. Jiménez-Jiménez, E. Rodríguez Castellón, Catal. Sci. Technol. 2016, 6, 3419-3429.

[27] I. Popescu, E. Heracleous, Z. Skoufa, A. Lemonidou, I.-C. Marcu, Phys. Chem. Chem. Phys. 2014, 17, 8138-8147.

[28] I. Popescu, Z. Skoufa, E. Heracleous, A. Lemonidou, I.-C. Marcu, Phys. Chem. Chem. Phys. 2015, 16, 4962-4970.

[29] J.M. López Nieto, B. Solsona, R.K. Grasselli, P. Concepcion, Top. Catal. 2014, 57, 1248-1255.

[30] a) D. Delgado, B. Solsona, A. Ykrelef, A. Rodríguez-Gómez, A. Caballero, E. Rodríguez-Aguado, E. Rodríguez-Castellón, J. M. López Nieto, J. Phys. Chem. C 2017, 121, 25132-25142; b) D. Delgado, R. Sanchís, J.A. Cecilia, E. RodríguezCastellón, A. Caballero, B. Solsona, J.M. López Nieto, Catal. Today 2019, 33, 10 16. 
[31] D. Delgado, B. Solsona, R. Sanchis, E. Rodríguez-Castellón, J.M. López Nieto, Catal. Today 2020, in press; https://doi.org/10.1016/j.cattod.2019.06.063.

[32] E.I. Ko, J.G. Weissman, Catal. Today 1990, 8, 27-36.

[33] J. Tauc, Mater. Res. Bull. 1968, 3, 37-46.

[34] B.D. Viezbicke, S. Patel, B.E. Davis, D.P. Birnie III, Phys. Status Solidi B 2015, $252,1700-1710$.

[35] S. Sathasivam, B.A.D. Williamson, S.A. Althabaiti, A.Y. Obaid, S.N. Basahel, M. Mokhtar, D.O. Scanlon, C.J. Carmalt, I.P. Parkin, ACS Appl. Mater. Interfaces 2017, 9, 18031-18038.

[36] J.N. Kondo, Y. Hiyoshi, R. Osuga, A. Ishikawa, Y.-H. Wang, T. Yokoi, Micropor. Mesopor. Mat. 2018, 262, 191-198.

[37] H.T. Kreissl, M.M.J. Li, Y.-K. Peng, K. Nakagawa, T.J.N. Hooper, J.V. Hanna, A. Shepherd, T.-S. Wu, Y.-L. Soo, S.C.E. Tsang, J. Am. Chem. Soc. 2017, 139, 1267012680.

[38] M. Grundner, J. Halbritter, J. Appl. Phys. 1980, 51, 397-405.

[39] B. Solsona, J.M. López Nieto, S. Agouram, M.D. Soriano, A. Dejoz, M.I. Vázquez, P. Concepción, Top. Catal. 2016, 59, 1564-1572.

[40] J. Zhang, M. Li, Z. Feng, J. Chen, C. Li, J. Phys. Chem. B 2006, 110, 927-935.

[41] C. Li, M. Li, J. Raman Spectrosc. 2002, 33, 301-308.

[42] N. Mironova-Ulmane, A. Kuzmin, I. Steins, J. Grabis, I. Sildos, M. Pärs, J. Phys. Conf. Ser. 2007, 93, 012039.

[43] R.E. Dietz, W.F. Brinkman, A.E. Meixner, H.J. Guggenheim, AIP Conf. Proc. 1972, $5,338-338$.

[44] V. Biju, M. Abdul Khadar, J. Nanopart. Res. 2002, 4, 247-253.

[45] V. Biju, Mater. Res. Bull. 2007, 42, 791-796.

[46] J.C. Vedrine, G. Hollinger, D. Tran Minh, J. Phys. Chem. 1978, 82, 1515-1520. 
[47] P. Salagre, J.L.G. Fierro, F. Medina, J.E. Sueiras, J. Mol. Catal. A Chem. 1996, 106, 125-134.

[48] M.A. van Veenendaal, G.A. Sawatzky, Phys. Rev. Lett. 1993, 70, 2459-2462.

[49] T. Blasco, J.M. López Nieto, Appl. Catal. A Gen. 1997, 157, 117-142.

[50] E. Rojas, J.J. Delgado, M.O. Guerrero-Pérez, M.A. Bañares, Catal. Sci. Technol. 2013, 3, 3173-3182.

[51] Z. Skoufa, E. Heracleous, A.A. Lemonidou, Chem. Eng. Sci. 2012, 84, 48-56. 
Table 1. Characteristics of support.

\begin{tabular}{lll}
\hline Sample & Characteristics of support & Egap (eV) \\
\hline Support A & Nb-free PCH & - \\
Support B & PCH with $5 \mathrm{wt} \%$ of $\mathrm{Nb}_{2} \mathrm{O}_{5}$ & 4.3 \\
Support C & PCH with $15 \mathrm{wt} \%$ of $\mathrm{Nb}_{2} \mathrm{O}_{5}$ & 4.5 \\
Support D & PCH with $30 \mathrm{wt} \%$ of $\mathrm{Nb}_{2} \mathrm{O}_{5}$ & 4.4 \\
\hline $\mathrm{Nb}_{2} \mathrm{O}_{5}$ & Hydrothermally synthesized $\mathrm{Nb}_{2} \mathrm{O}_{5}$ & 3.5 \\
\hline
\end{tabular}


Table 2. Characteristics of catalysts.

\begin{tabular}{|c|c|c|c|c|c|c|c|}
\hline Sample & $\begin{array}{l}\mathrm{NiO} \\
\text { wt.\% }\end{array}$ & $\begin{array}{l}\mathrm{Nb}_{2} \mathrm{O}_{5} \text { in } \\
\text { the support }\end{array}$ & $\begin{array}{c}\mathrm{S}_{\mathrm{BET}} \\
\left(\mathrm{m}^{2} / \mathrm{g}\right)\end{array}$ & $\begin{array}{c}\mathrm{NiO} \\
\text { Crystallite } \\
\text { size }(\mathrm{nm})^{\mathrm{a}}\end{array}$ & $\mathrm{H}_{2}$-uptake ${ }^{b}$ & $\begin{array}{l}\mathrm{LO}(1 \mathrm{P}) / \\
2 \mathrm{LO}(2 \mathrm{P})^{\mathrm{c}}\end{array}$ & $\begin{array}{l}\text { Egap } \\
(\mathrm{eV})^{\mathrm{d}}\end{array}$ \\
\hline 50NiO/A & 50 & 0 & 244 & 11 & 260 & 1.05 & 3.7 \\
\hline 50NiO/B & 50 & 5 & 246 & 9.6 & 228 & 1.47 & 4.0 \\
\hline $50 \mathrm{NiO} / \mathrm{C}$ & 50 & 15 & 263 & 5.8 & 231 & 1.67 & 4.0 \\
\hline 50NiO/D & 50 & 30 & 165 & 26.1 & 269 & 0.43 & 3.7 \\
\hline $20 \mathrm{NiO} / \mathrm{C}$ & 20 & 15 & 317 & 4.5 & 99 & n.d & n.d \\
\hline $80 \mathrm{NiO} / \mathrm{C}$ & 80 & 15 & 68 & 32.1 & 403 & n.d & n.d \\
\hline $50 \mathrm{NiO} / \mathrm{Nb}_{2} \mathrm{O}_{5}$ & 50 & 100 & 61 & 12.4 & 248 & n.d & 3.6 \\
\hline $\mathrm{NiO}$ & 100 & 0 & 15 & 27 & 490 & n.d & 3.6 \\
\hline
\end{tabular}

a) Mean $\mathrm{NiO}$ crystallite size estimated by the Scherrer equation through the XRD patterns; ${ }^{\text {b) }}$ hydrogen consumption in the TPR experiments, in $\mathrm{mL} / \mathrm{g}$; ${ }^{\mathrm{c}} \mathrm{LO}(1 \mathrm{P}) / 2 \mathrm{LO}(2 \mathrm{P})$ bands ratio in the UV-Raman spectra;

d) Ban gap of pure $\mathrm{Nb}_{2} \mathrm{O}_{5}$ of $3.5 \mathrm{eV}$. 
Table 3. Catalytic results in the ODH of ethane. ${ }^{a}$

\begin{tabular}{|c|c|c|c|c|c|c|}
\hline Catalyst & $\begin{array}{l}\text { Ethane } \\
\text { conversion (\%) }\end{array}$ & $\begin{array}{l}\text { Selectivity to } \\
\text { ethylene }(\%)\end{array}$ & Catalytic activity $^{\text {b }}$ & $\begin{array}{l}\text { Catalytic Activity per } \\
\mathrm{NiO} \text { loading }{ }^{\mathrm{c}}\end{array}$ & $\begin{array}{l}\text { STY rate of product } \\
\text { formation }^{d}\end{array}$ & TOF $^{\mathrm{e}}$ \\
\hline 50NiO/A & 4.5 & 38.6 & 330 & 659 & 119 & 4.56 \\
\hline 50Ni0/B & 7.5 & 67.1 & 549 & 1099 & 334 & 7.60 \\
\hline $50 \mathrm{NiO} / \mathrm{C}$ & 12.7 & 87.5 & 930 & 1860 & 760 & 12.9 \\
\hline 50NiO/D & 11.7 & 64.1 & 857 & 1713 & 513 & 11.9 \\
\hline $20 \mathrm{NiO} / \mathrm{C}$ & 4.2 & 75.2 & 305 & 1530 & 215 & 10.6 \\
\hline $80 \mathrm{NiO} / \mathrm{C}$ & 11.1 & 53.9 & 813 & 1016 & 409 & 7.02 \\
\hline$\overline{50 N i O} / \mathrm{Nb}_{2} \mathrm{O}_{5}$ & $13.4^{\mathrm{e}}$ & 59.7 & 1961 & 3923 & 1094 & 27.2 \\
\hline $\mathrm{NiO}$ & $7.5^{\mathrm{e}}$ & 33.3 & 1098 & 1098 & 339 & 7.6 \\
\hline
\end{tabular}

a) $\mathrm{At} 450^{\circ} \mathrm{C}$ and a contact time, W/F, of $4 \mathrm{~g}_{\mathrm{cat}} \mathrm{h} \operatorname{mol}_{\mathrm{C} 2}{ }^{-1}$; b) Catalytic activity (in $\mathrm{g}_{\mathrm{C} 2 \mathrm{H} 6} / \mathrm{kg}_{\mathrm{cat}} \mathrm{h}$ ); ${ }^{\mathrm{c})}$ Catalytic activity per loading of $\mathrm{NiO}$ (in $\mathrm{g}_{\mathrm{C} 2 \mathrm{H} 6} / \mathrm{kg}_{\mathrm{NiO}}$

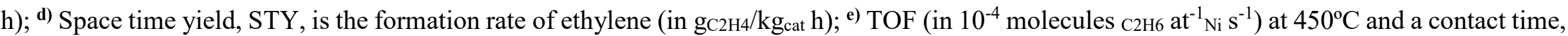
$\mathrm{W} / \mathrm{F}$, of $2 \mathrm{~g}_{\mathrm{cat}} \mathrm{h} \mathrm{mol}_{\mathrm{C} 2}{ }^{-1}$. 


\section{Caption to figures}

Figure 1. Diffuse reflectance UV-VIS spectra and their corresponding Tauc plots of supports. a) Support A (PCH); b) Support B (5 wt.\% $\mathrm{Nb}_{2} \mathrm{O}_{5}$ on PCH; c) Support $\mathrm{C}$ (15 wt.\% $\mathrm{Nb}_{2} \mathrm{O}_{5}$ on $\left.\mathrm{PCH}\right)$; d) Support D (30 wt.\% $\mathrm{Nb}_{2} \mathrm{O}_{5}$ on $\left.\mathrm{PCH}\right)$; e) $\mathrm{Nb}_{2} \mathrm{O}_{5}$.

Figure 2. $\mathrm{Nb} 3 \mathrm{~d}$ core-level XPS spectra of $\mathrm{Nb}$-containing supports, i.e. supports $\mathrm{B}, \mathrm{C}$ and D. For comparison the spectrum of pure $\mathrm{Nb}_{2} \mathrm{O} 5$ has been also included.

Figure 3. XRD patterns of supported $\mathrm{NiO}$ catalysts. Characteristics of catalysts in Table 1. For comparison the XRD patterns of pure $\mathrm{NiO}$ and support $\mathrm{C}$ has been also included.

Figure 4. TEM images and their corresponding EDX maps of supported $\mathrm{NiO}$ catalysts with 50 wt $\%$ of $\mathrm{NiO}: 50 \mathrm{NiO} / \mathrm{A} ; 50 \mathrm{NiO} / \mathrm{B} ; 50 \mathrm{NiO} / \mathrm{C}$; and $50 \mathrm{NiO} / \mathrm{D}$.

Figure 5. UV-Raman spectra of supported $\mathrm{NiO}$ catalysts with $50 \mathrm{wt} \%$ of $\mathrm{NiO}$ : $50 \mathrm{NiO} / \mathrm{A}$; $50 \mathrm{NiO} / \mathrm{B} ; 50 \mathrm{NiO} / \mathrm{C}$; and $50 \mathrm{NiO} / \mathrm{D}$.

Figure 6. $\mathrm{TPR}-\mathrm{H}_{2}$ profiles of: a) Supported $\mathrm{NiO}$ catalysts, using Support C (i.e. with 15 wt. $\% \mathrm{Nb}_{2} \mathrm{O}_{5}$ on $\left.\mathrm{PCH}\right)$; b) supported $\mathrm{NiO}$ catalysts with $50 \mathrm{wt} \%$ of $\mathrm{NiO}$.

Figure 7. Ni $2 p$ core-level spectra of supported $\mathrm{NiO}$ catalysts with $50 \mathrm{wt} \%$ of NiO: a) $50 \mathrm{NiO} / \mathrm{A}$; b) $50 \mathrm{NiO} / \mathrm{B}$; c) $50 \mathrm{NiO} / \mathrm{C}$; and d) $50 \mathrm{NiO} / \mathrm{D}$.

Figure 8. $\mathrm{Nb} 3 d$ core-level spectra of $\mathrm{Nb}$-containing supported $\mathrm{NiO}$ catalysts with 50 wt $\%$ of $\mathrm{NiO}$ : a) $50 \mathrm{NiO} / \mathrm{B}$; b) $50 \mathrm{NiO} / \mathrm{C}$; and c) $50 \mathrm{NiO} / \mathrm{D}$.

Figure 9. Influence of $\mathrm{NiO}$ loading (for catalysts of $\mathrm{xNiO} / \mathrm{C}$ series) (a) and influence of $\mathrm{Nb}$-loading (for catalysts with $50 \mathrm{wt} \%$ of $\mathrm{NiO}$ ) (b) on catalytic activity (in g C $2 \mathrm{H} 6$ $\mathrm{kg}_{\mathrm{cat}}{ }^{-1} \mathrm{~h}^{-1}$ ) during the $\mathrm{ODH}$ of ethane on supported $\mathrm{NiO}$ catalysts. Reaction conditions: $\mathrm{C}_{2} / \mathrm{O}_{2} / \mathrm{He}=3 / 1 / 26$ molar ratio, $\mathrm{T}=450^{\circ} \mathrm{C}$ and $\mathrm{W} / \mathrm{F}=4 \mathrm{~g}_{\text {cat }} \mathrm{h}$ mol $_{\mathrm{C} 2}{ }^{-}$ 1 .

Figure 10. a) Variation of the selectivity to ethylene as a function of NiO-loading on Support C (15 wt.\% $\mathrm{Nb}_{2} \mathrm{O}_{5}$ on $\mathrm{PCH}$. b) Variation of the selectivity to ethylene (at $10 \%$ ethane conversion) as a function of ethane conversion for supported 50 wt.\% NiO catalysts. Reaction conditions as in Fig. 9. 


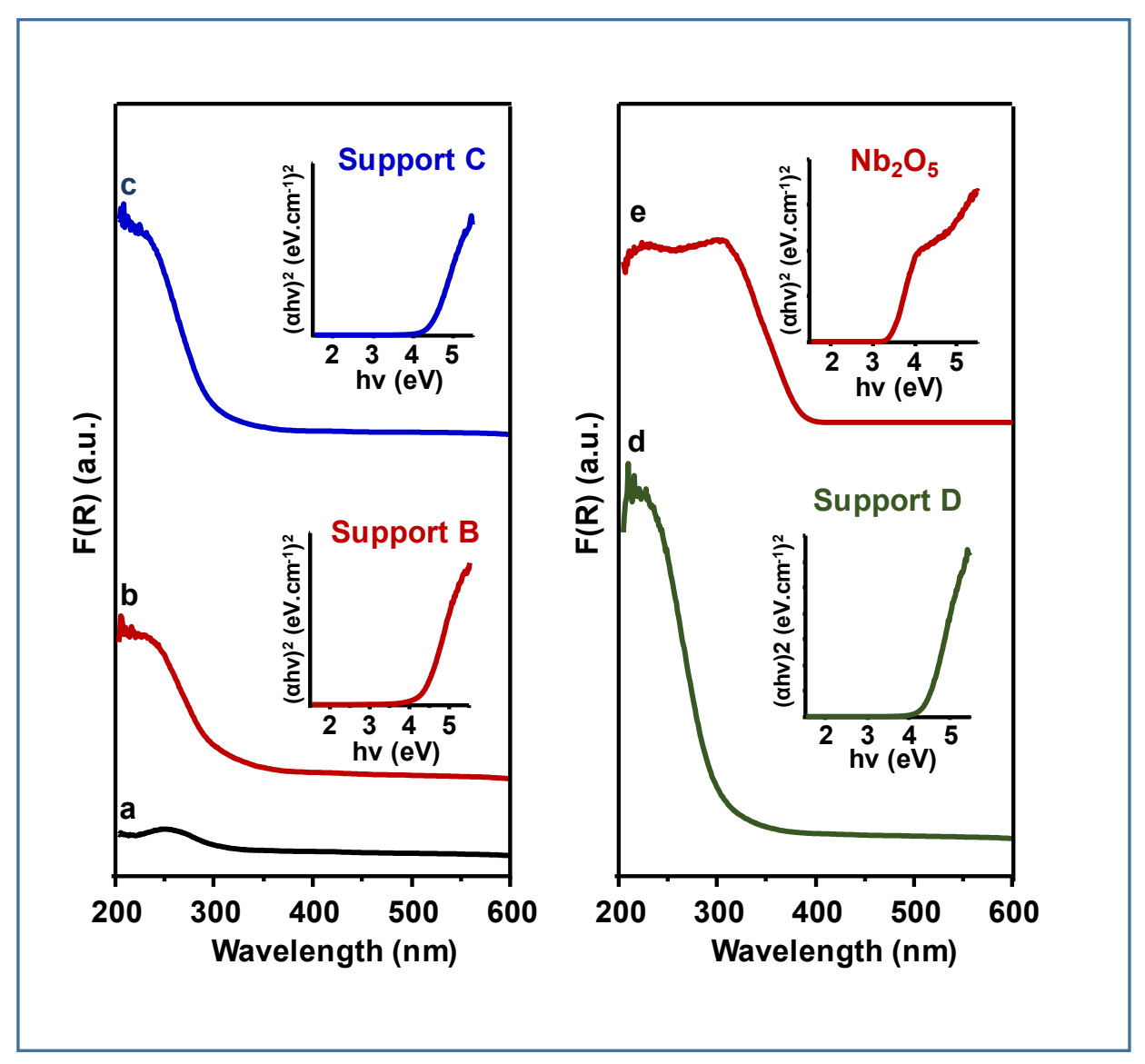

Fig. 1

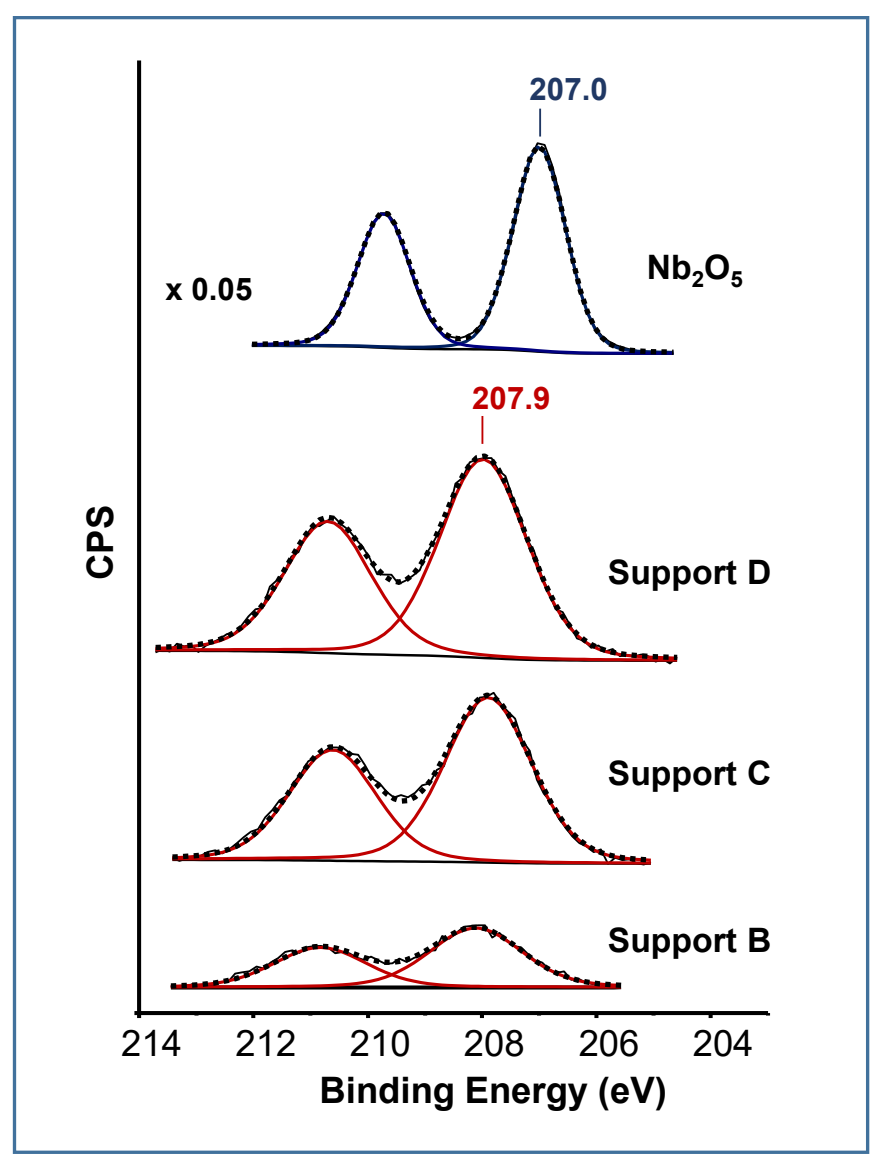

Fig. 2 

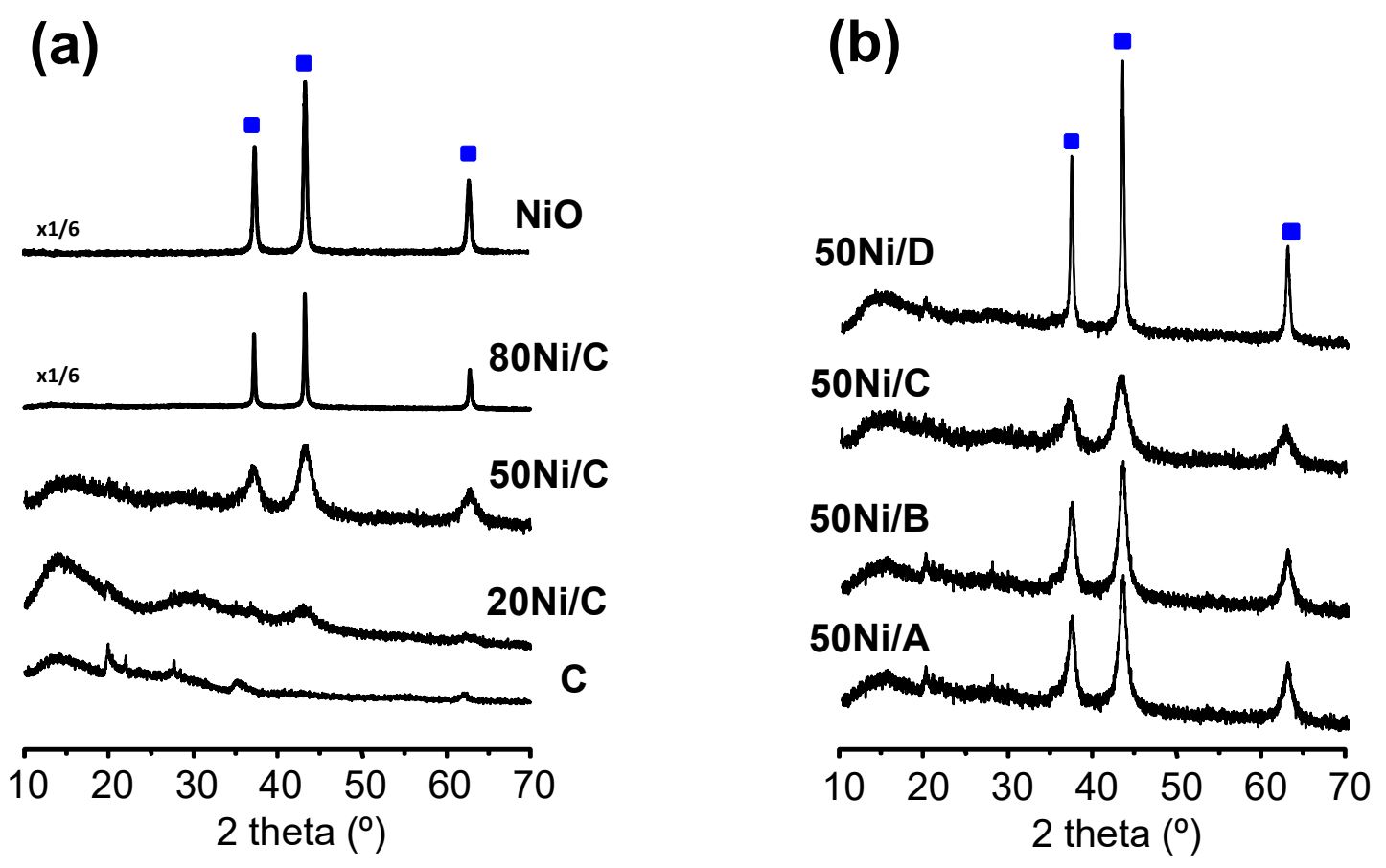

Fig. 3 


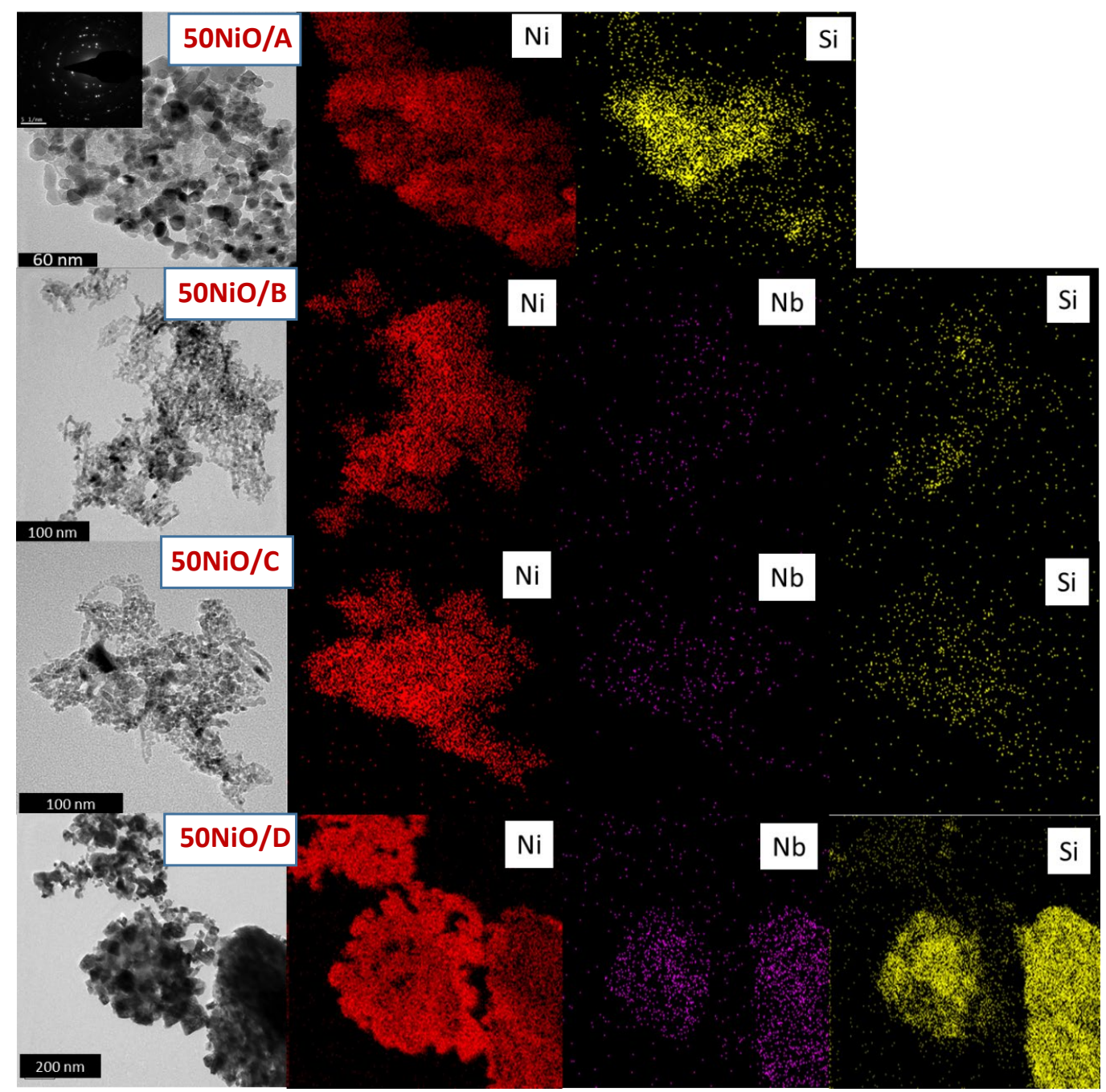

Fig. 4 


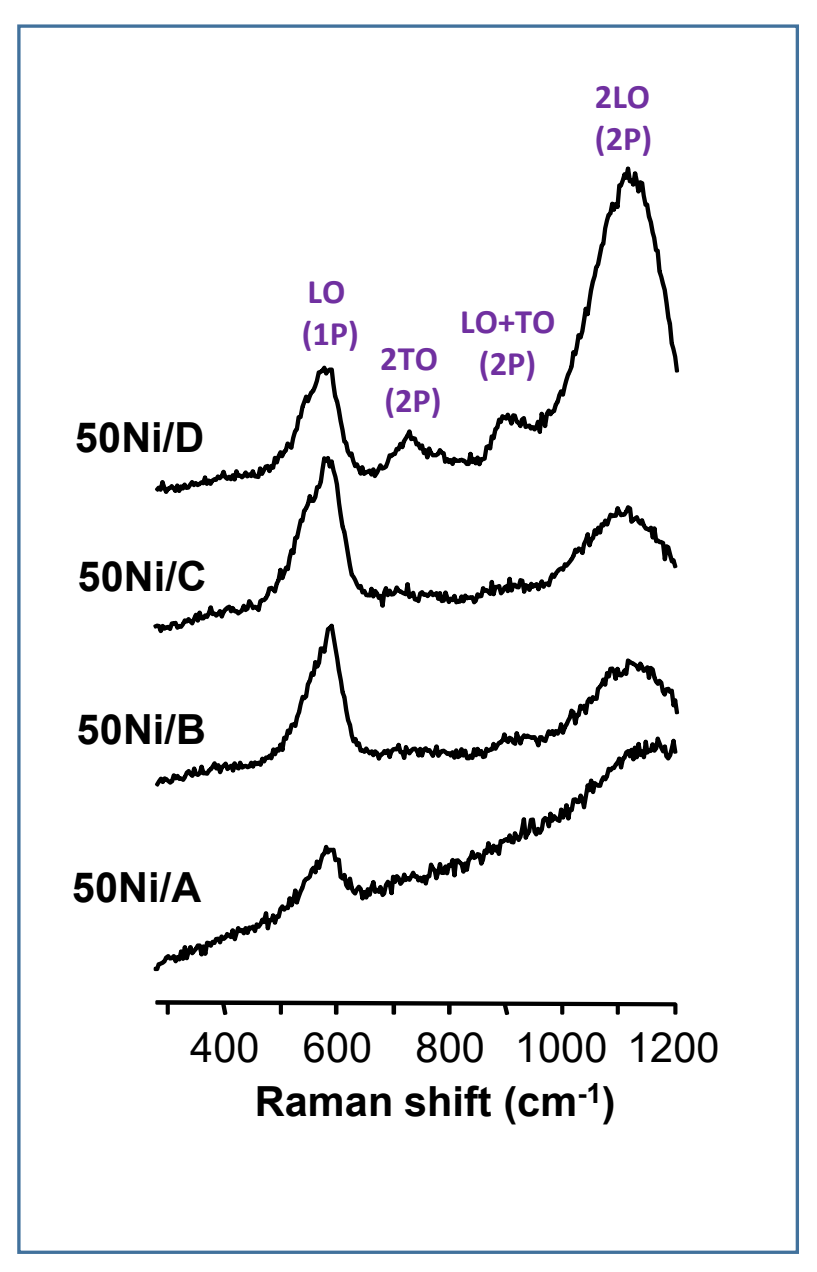

Fig. 5

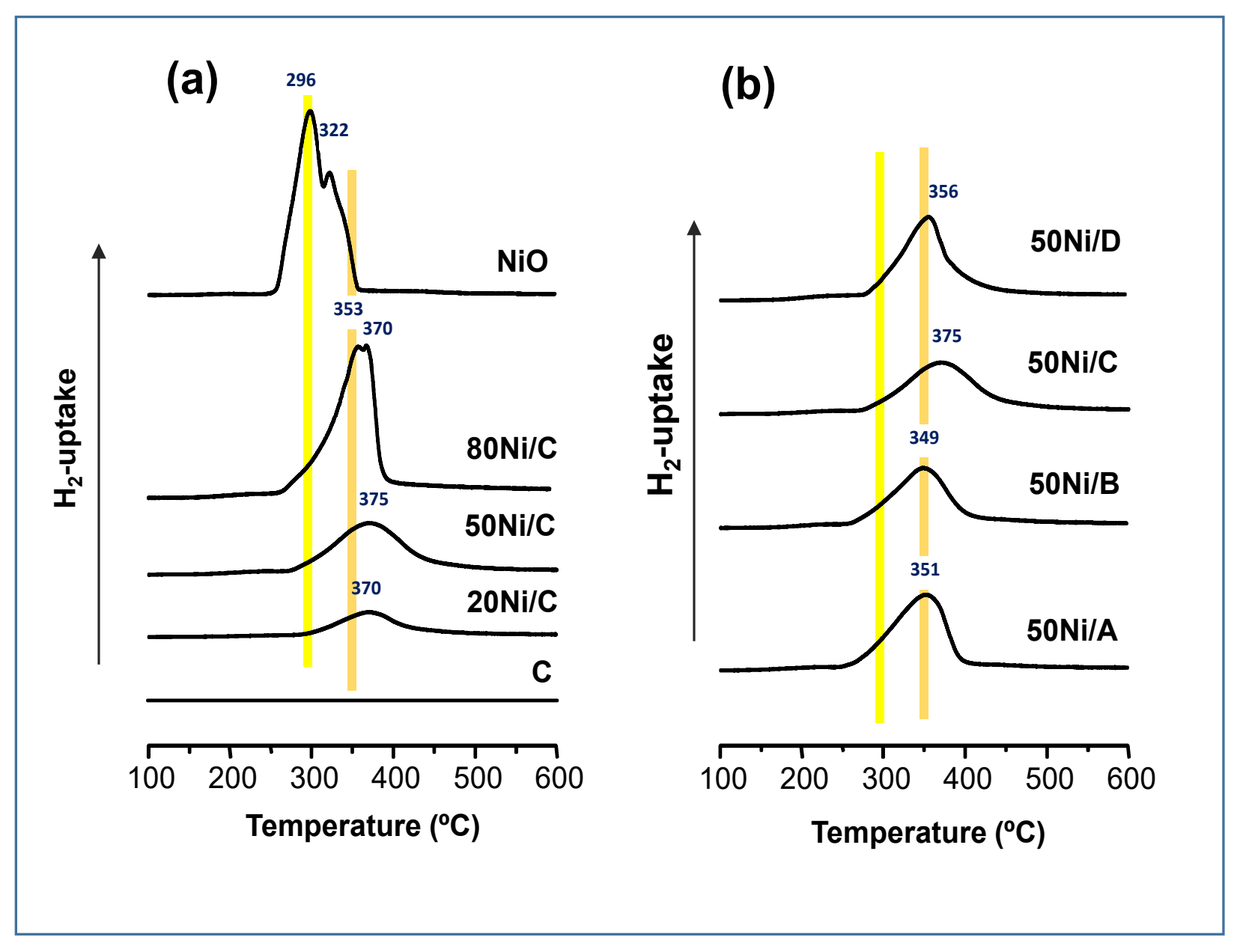

Fig. 6 


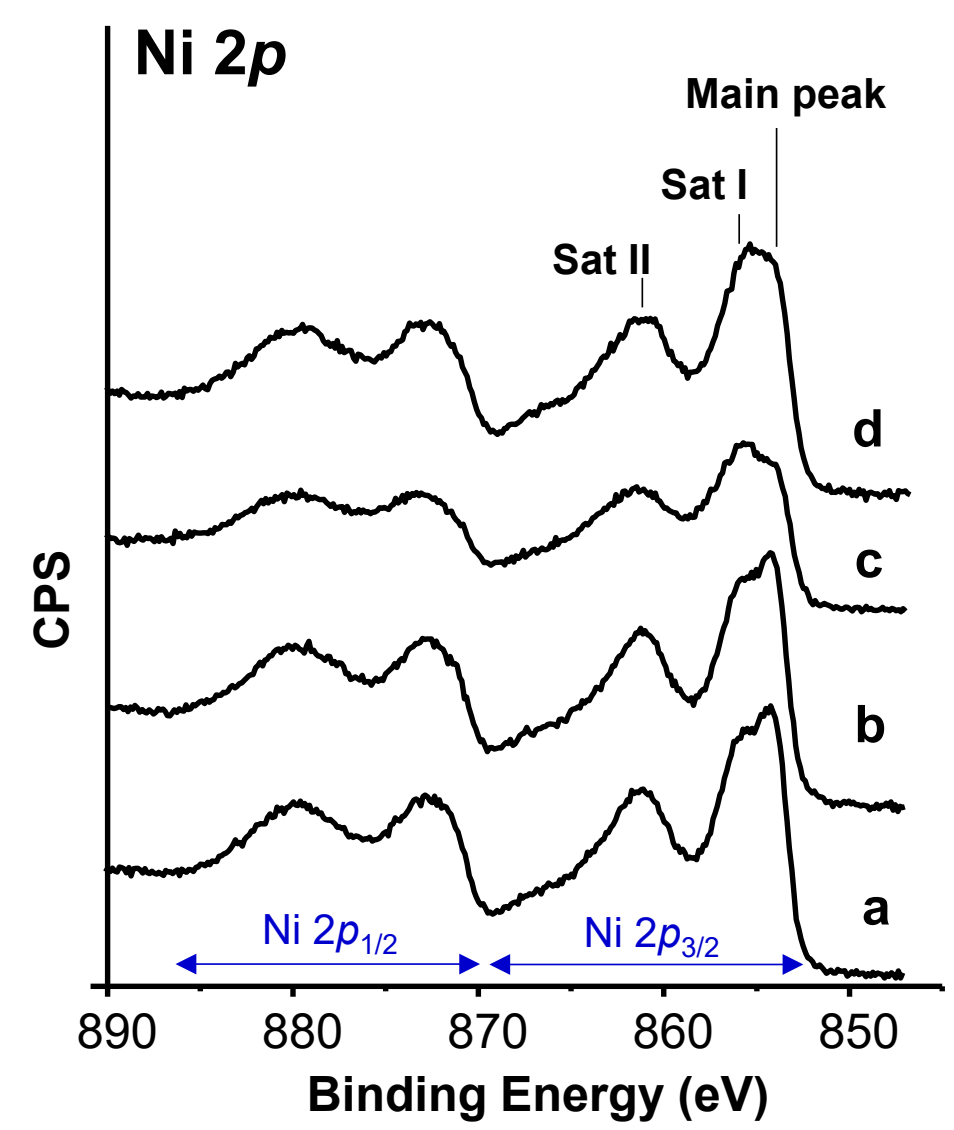

Fig. 7

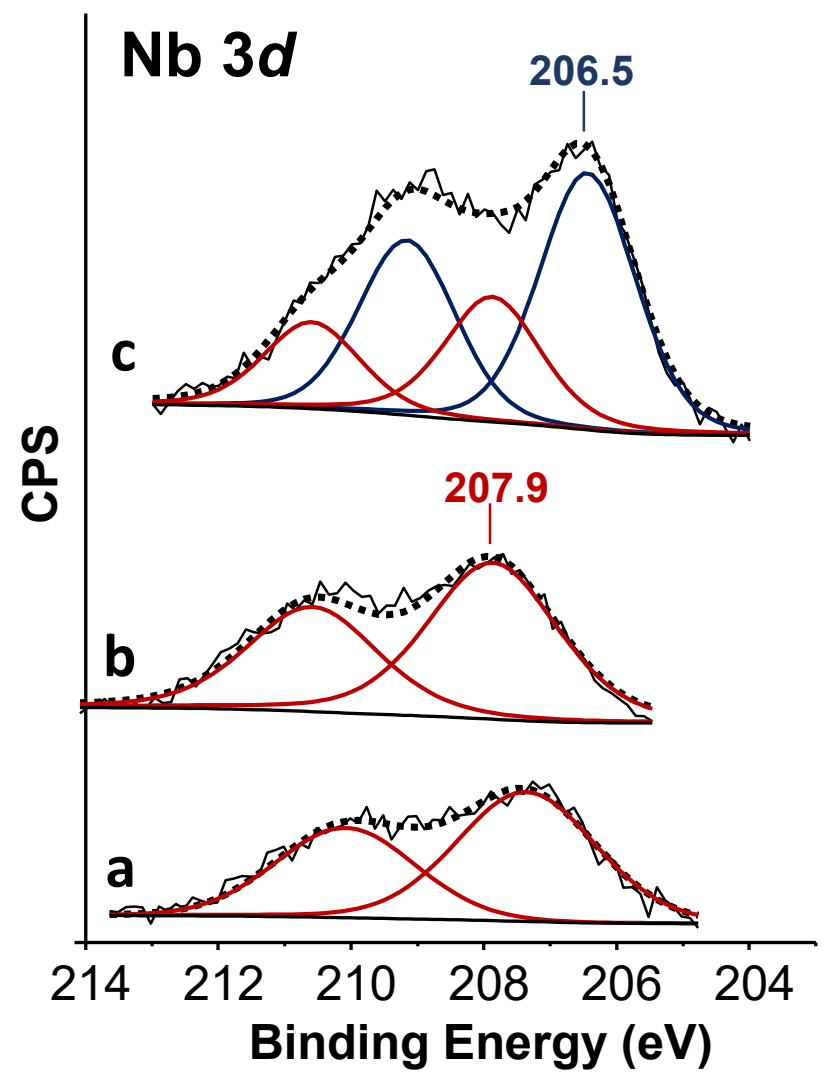

Fig. 8 
Fig. 9
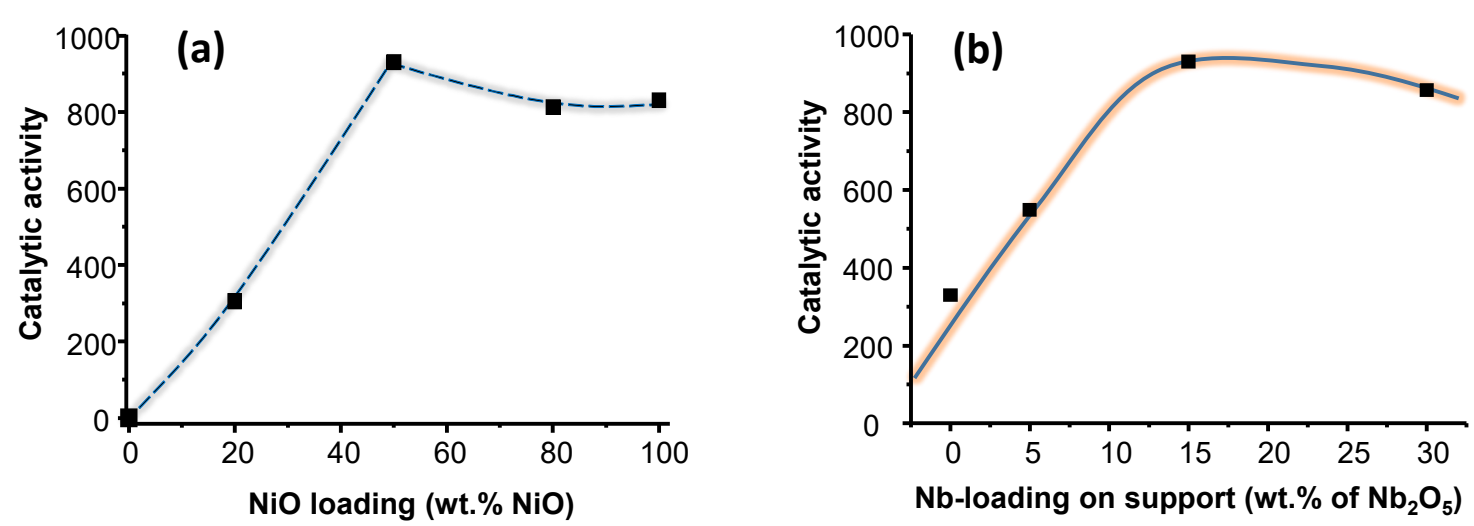

Fig. 10
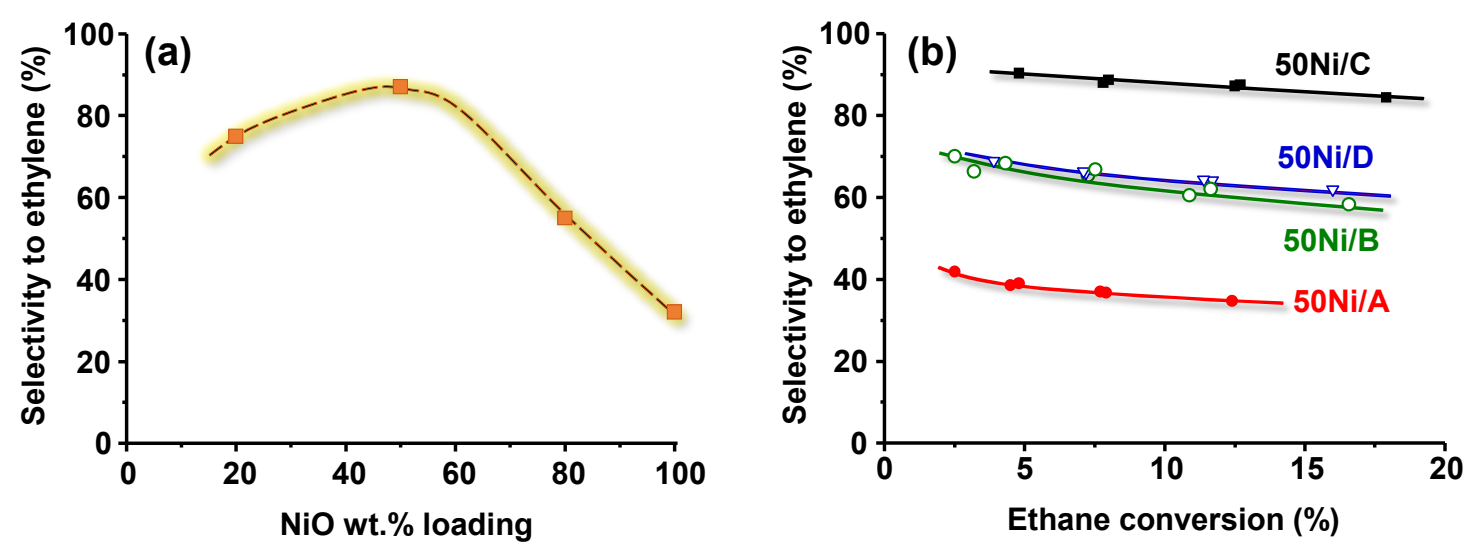


\section{Table of Contents}

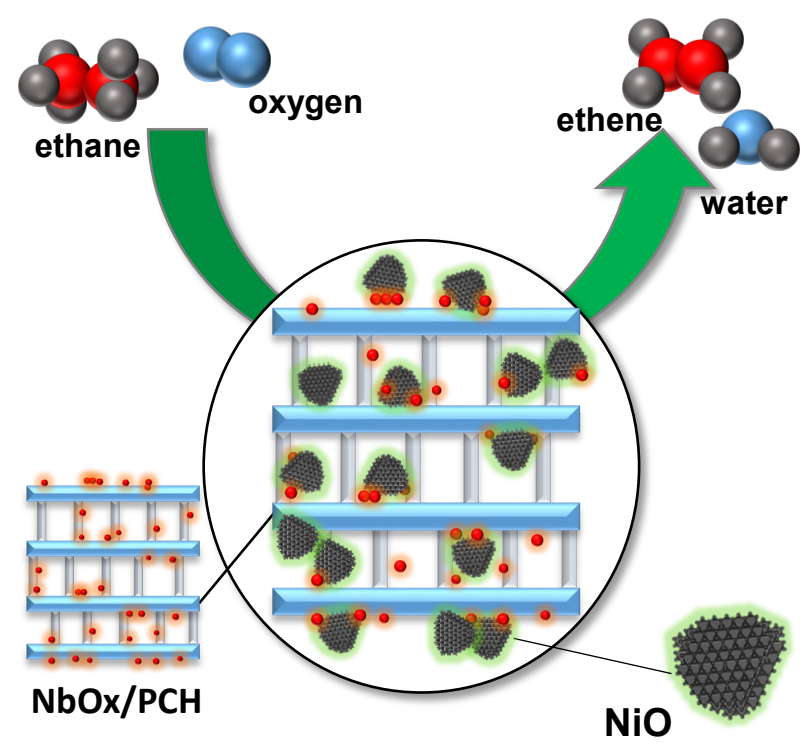

$\mathrm{NiO}$ supported on a $\mathrm{Nb}$-containing porous clay heterostructure $(\mathrm{PCH})$ shows outstanding catalytic properties in the $\mathrm{ODH}$ of ethane (ca. 90\% selectivity to ethylene). Controlling the chemical nature of $\mathrm{Nb}^{5+}$ species on $\mathrm{PCH}$ is the key factor to achieve an effective $\mathrm{NiO}$ support interaction. 